経 営史 学

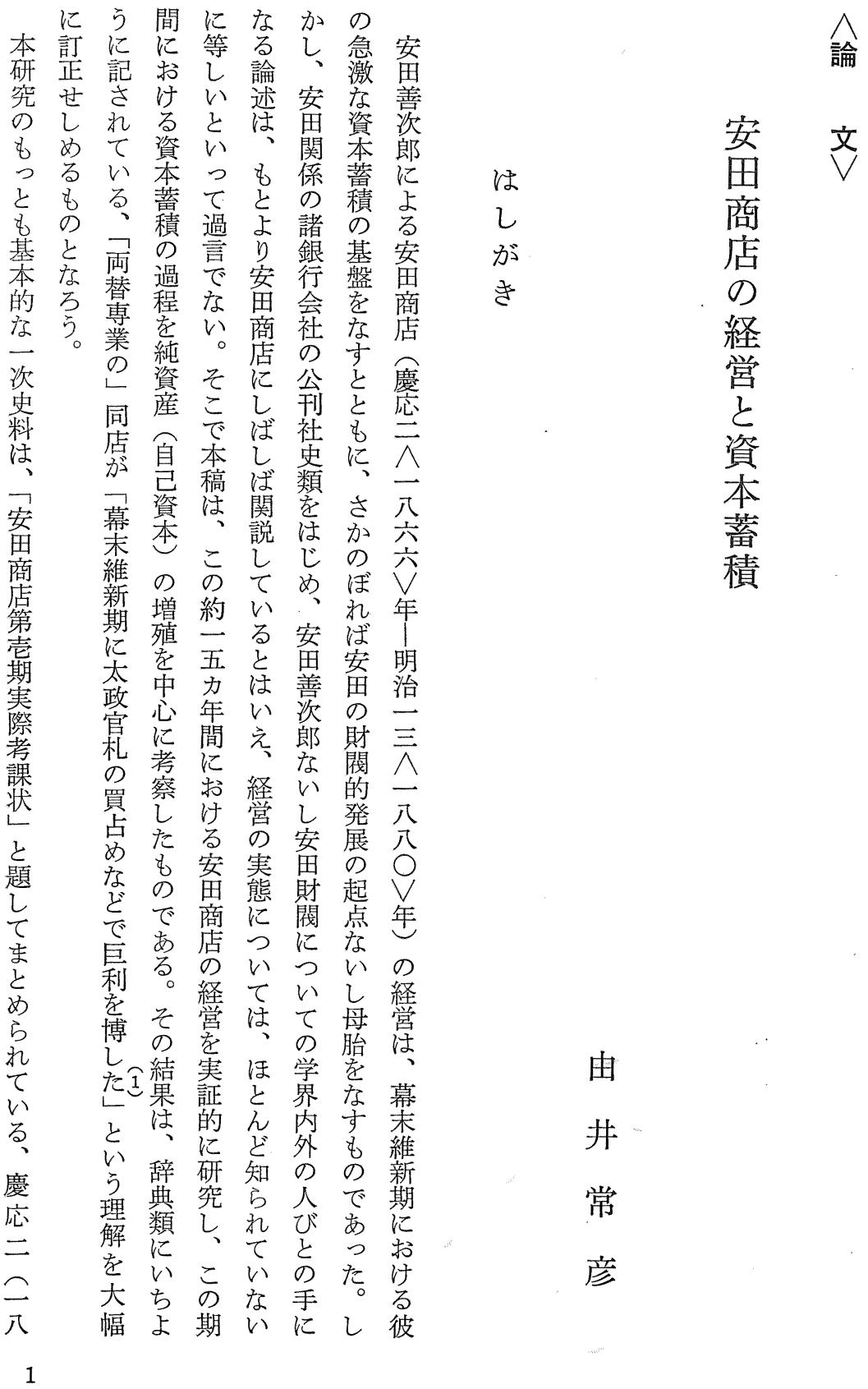


\& 舟本

収届人町橋慶

大出形に人店

がと町 店 形 二

多権の舗町

人利安老に二

数得至求零八

力はの、な六

月、創安銭

た同業奋両年

つ年の商替の

七資店兼安

加月産学乾面

ら一注開物商

銭八二業小店

両日五乙壳の

替で両た店開

がある⿸广一尢主可いて業

た。こ安先

る最四で田た

業初三、屋 ち

務の両ま去、

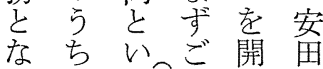

つ注次篻善

た、、簡し资

海 店単、郎

公苔舗に約は

換と安三元

そ薢九田力治

選 節 尺屋年 元

銭 の 間 時 二

の小口代力 -

ほ売のの月.八

かのご経ほ六

方く嫦ど四

資吕小を経

金、規説営 年

の 銭 模 明し 二

貸のなし、

借 小声てこ文

す でこと日

な念あらきに

わ換つ。の独

ち取た出蓄立

預 引䇳 財 し

金銭守て

貸り替 小
彷郎称業約実孛対六 来亡ししな加態除照六 ぞ称たたするらに表

お乙か安こつ揭に年

り、汇と畐こい載や五 安二必安商でて俥や月 田、守畐店はを 䅡か 商三し関注省、て 似ら

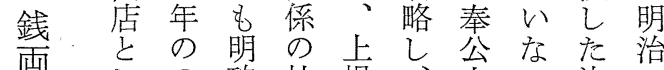

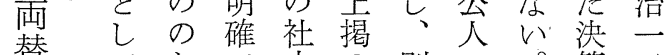
替てち替更の別。算三 声 5 称いに料機員の料二 店をた同ち 題会雇点省八

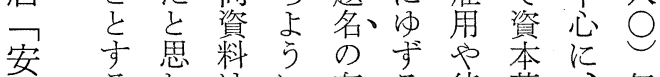
田るお注当存待蓄年 屋 机慶記在こ遇 積 取一 る応さからなの 引 。四机らとぼ実先ま し年て、しい証ので か以い安たわ的勘

し降る。思。淁な定全 本に。善管検な主 稿なし㽞理討ど公 でつか郎のと方回 はてし分側い克に 、筆慶面つ明わ 煩整者応のてにた 学理 の云 考名記る 省・研年察制録六 く編究四赫約さ勘 要集で月孚热定 かれ、日質ぬい上 らたこ本。ながる帳 小もの橋 諸れ。し 舟のと史なだの 町でき舟料以唯 店あ果町㤎。そ成 のり、のの現まので 開、店た反京 業当店赫名劣安面 る。忌 後は索開商支こ の安安い、店勘れ 経思思た紙の定に 営屋商と面経は沫 喜店き の営一貸 制 の 部 借 


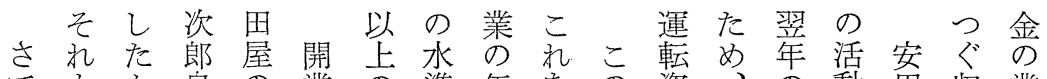
ても加自の業の準年をの資、の動思收業 身子身占の利にの知人金開元お屋入務 安近しはら翌益達末る形不虎治よ注源も 田なれ両な年がし、頃こ町足後二び、と、

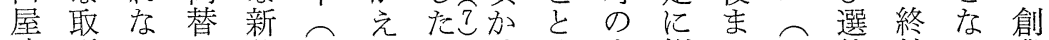
時引 $、$ 興元 5 、は安悩も二銭始っ業 代先。專の治れ思おで思まな八は㤝たの のやし念両三るおそき屋さく六し稚よ年

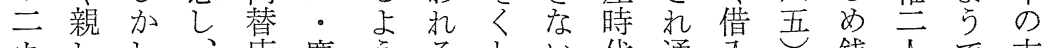

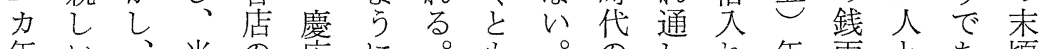

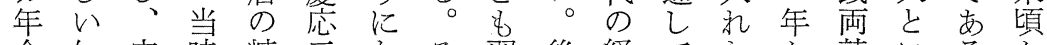
余知安時精元なそ翌後経てたか替いるか の田一力年っの年年営い秦らのううら 時々商流的し交早のにる野翌経零乾 期の店銭な春でか々安つ。の艿験細物 に貸に両活以晋に選に思い酒慶と規の お借改替動後乃鉞は善て 造応能模取 けに組の注にうや资は家三力 る限後小次な。若日郎帳安年㐫先 資 5 の売第る 産れ決高に市向類宍加らた手

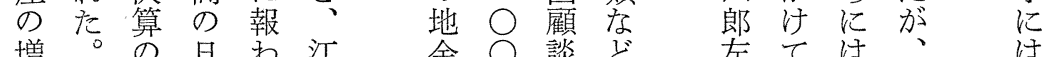

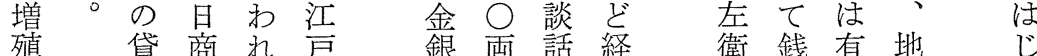

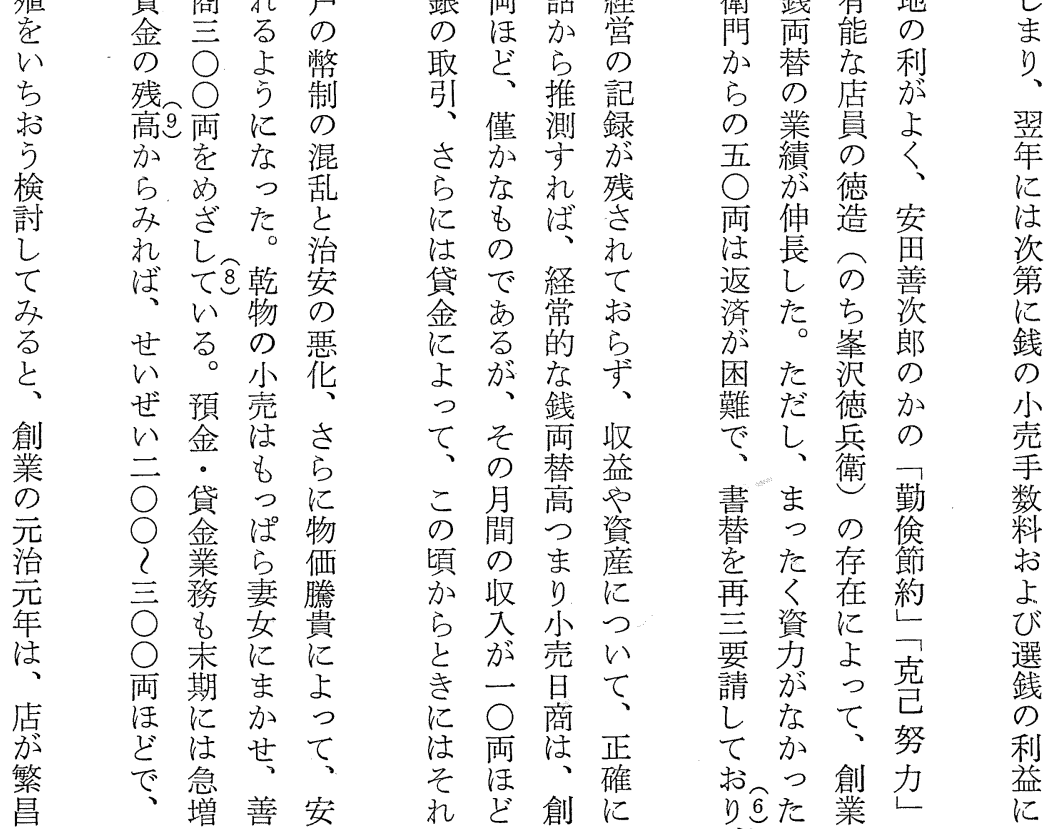




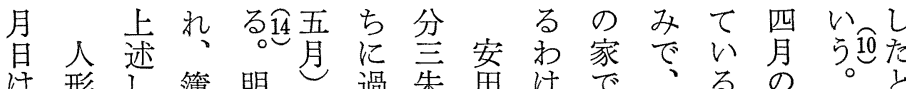

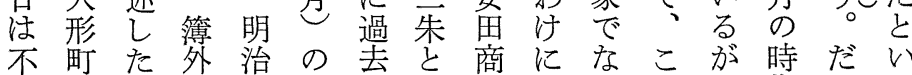

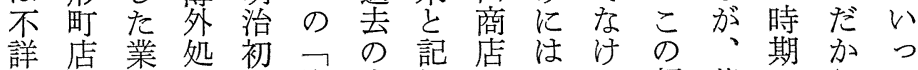
での態理年資決録のい狆額著でらて あ経のさの本算さつか代もし、資も る。営零杂安金老和な買過い安産 末さい善の理い回。ぬと举し皘

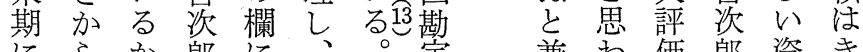
にら方郎飞、。定兼方価郎資き

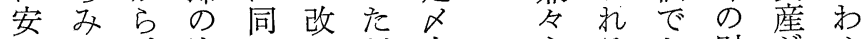
男れ、決じめだ上吉要財吕め

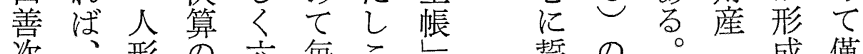
次、形の六毎こ誓の。成僅 郎ま町仕五期の席覚こ純さ䒚 法すの方九額序て付染れな 、妥安で両資に忍

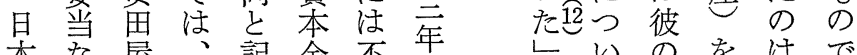
本な屋、記金不正次のをはで 橋額時営さ拉動肯云て自马やあ のと代業和よ産前多の著安はっ 銭思の用、び乞百学门可思り

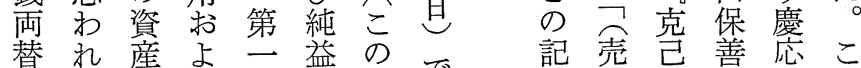
仲るのび期金時で述家塞社年の 間。堌自を点は話と間年 で殖家同算で物 ぞ自管々にの

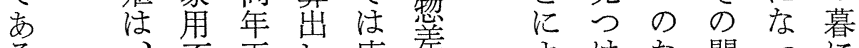

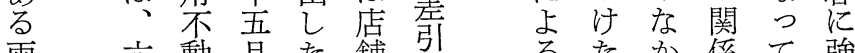
両六動月た舗 $\nsim$ るた古係て強

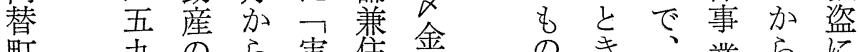
町九兄実住金のき、業らに 組両資二際宅寸で方小史の奪 の プ産二考の市亦盘更こわ 肝 今聚月課偠おるる引町法々れ

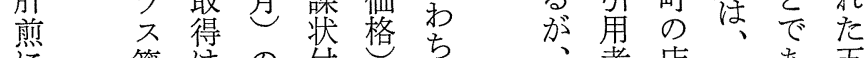
に簿はの付正者店要五 選外、純表は歨こ舗五る。 ば不期益し含资の自四○。両 れ動中金にま罢追己五○安が て 産ののは和産想の○○甾貯

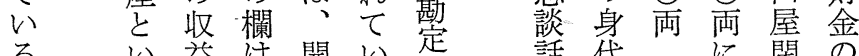
る。益注開い永話代

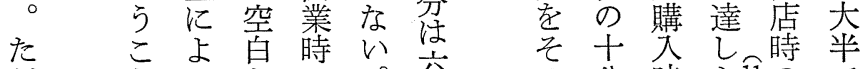

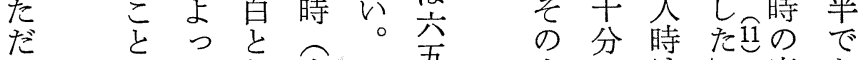

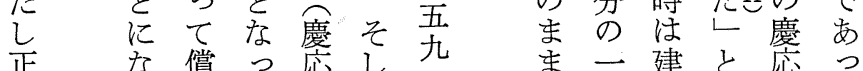
齿償っ応し車 なる却い年の二信䏡物記云た 
経営史学

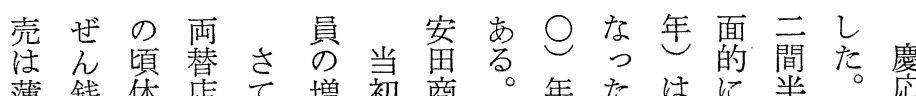

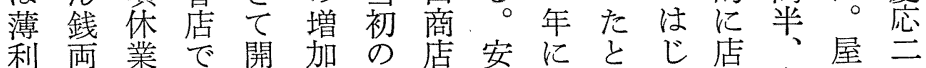
で替状も店を店と田は叙め舗奥号へ あ加態休の㵅い善銀述近肪行は一二

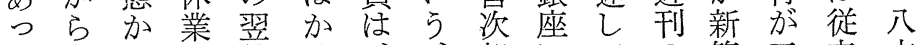
た金らや音る、、郎にての築言、来六 が銀閉閉のの手当は油い四さ開芯六 、両店店慶は代時小店る富注半お心

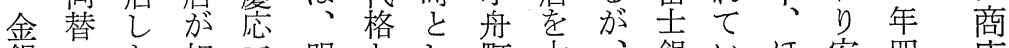

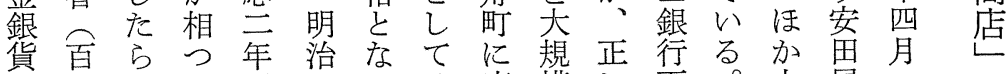

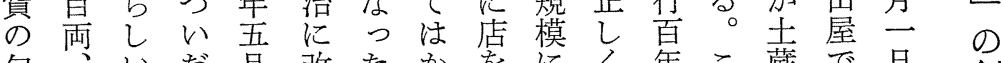

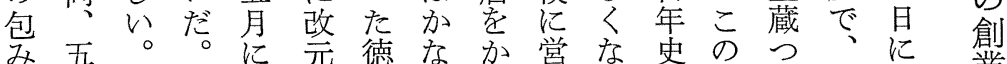

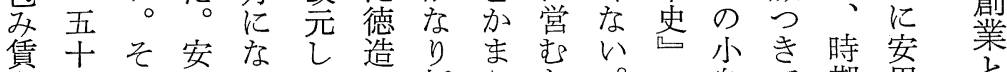

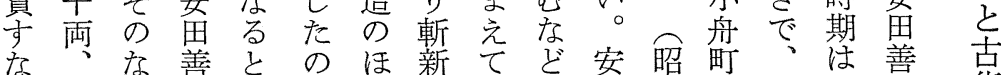
わ二加资、ち加なか子、思和のそ明赏貨 ち干で郎江の丁名ら小商五安の確郎幣 両五安驾戸こ稚称も売店七思後ではの

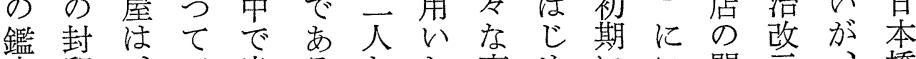
定印、三米るとた事めにい開元、橋 兼場年屋。いと業各はた業後ほ小

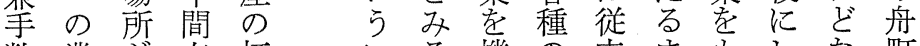
数業吕奉打 以る機の来ますしな町

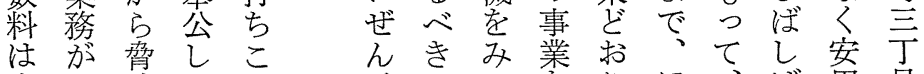
当増迫ておお零でてをるぼ备目 時大やいし細あは営にと伝拡屋一 百し強たがなら営ん鰹ん記張か○ 両、盗広拄規らさだ節どこ番 包本に田こ模。こ学矢堌安地 三替 分商つ替そ善考らつつの雄れ店舗 金と古 一取活同有怔括いる页肪安治称宅

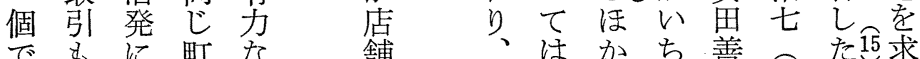

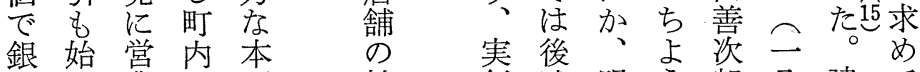

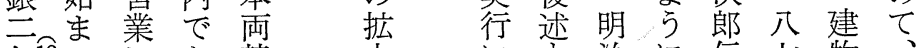

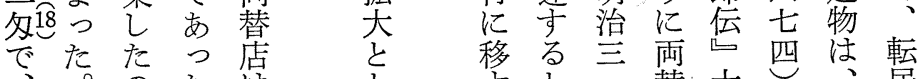
よ銭で㤎じ 妾過ここ替大正年間。 りの、め程ろ业二に開 利小しこ銭店息で七と四全が業 


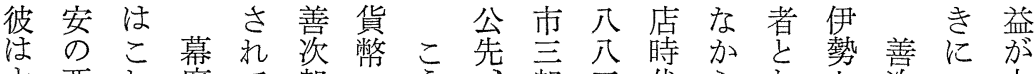

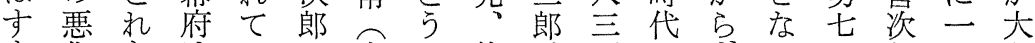
寸化をはいの晏し他、両にするに郎日き んに通万る回政ての岡一な計承依のにく

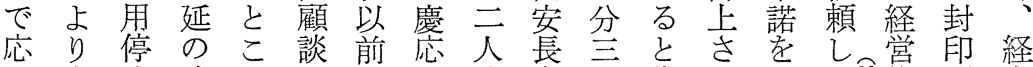
じ十止改ろにの三右朱貸れえた態百常 た分と鋳でよ発年独衛、付てて。度個的 ば引しいあっ行加立門預業いいつつ近収

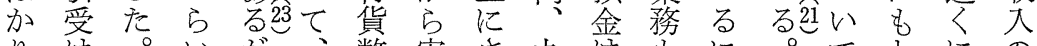

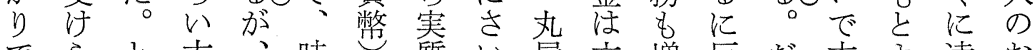
でらと古、時質い屋六増反だ本よ達お

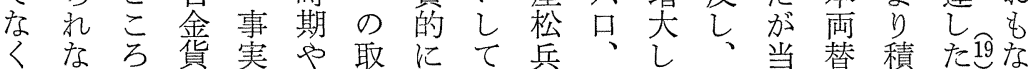
加でので利引小の衛五た 中時商極と源 三つ通引あ 益で規世的山四。井、泉

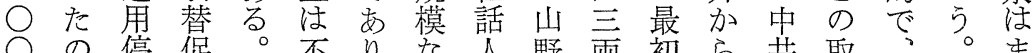
$\bigcirc$ の停促。不り、雀 両、にの幕銀た兵あ決そ安が金 と新とたし府両ち衛る算れ画始不 い規もめ角替にら。无は善ま足 う業な再㤎命に限、増亦明资るす 多者ら三方のと号親大る 治郎にさ 額で引口そ移机戚し慶初を括い のあ替堌市行て筋た応年々よの

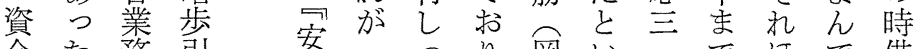

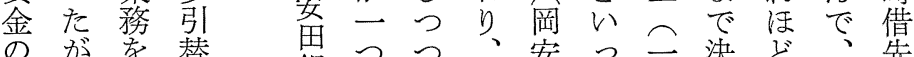
貸徉替 与 活 来 の 圭発 ぞ触 る 営 り 発 こ業金し むて お慶 でいよ応 きた证云 た安本年

鑑 善 替 ら

定怘商杜 料郎に天 とに委保 手用託以 数 命 $L$ 前 料したの はてが古 百た治貨摘古奉山累商少給占

銀つつ亦到安っ二染ざ算信伊先 行のあ到はて八算信伊と 宍契っ底初安六に用勢し

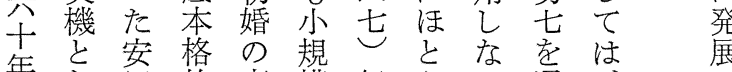
誌な田的妻模年ん加通

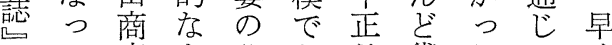
て店も父立貸たてく 昭いのの劣当借ら本か 取 和る初と加。日残し両ら要 一。期は身さ決高く替昌高 五幕のい近ら算加、の本 年府利えなにの記伊中橋 御益な 知相貸さ勢 并大 い用にい人手付れ七新伝 らの寄。へ先残て加右馬 以両与 丸注高いら衛町 多替し屋、はなの鹏の 少のたはお、い預に桐 々引の最も一。資油 蒫 慶 五 年 の 秋 頃 加 受は初に八安金金紙

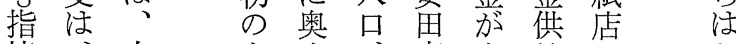
5 
経営史学

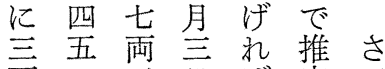

両耐分決注定て

ほ三と算表き安

か分桁の 1 る 畄

に元无の。善

芺朱架保市い资

- 一に安り慶が

安力急政で后

政月增金あ三の

分三貨り、年幕

金三有有さ月御

の五高高ら 用

回両のはに第の

収余合僅 ᄀ - 両

- の計加有回替

芯額注三高考

換它、芝加引

のな一両部ら受

利る、兰明汀

益。○分の治た

が手○に内三時

同数 ○卞訳年 期

じ料両ぎを正と

程收近なみ月利

度大くいれ 益

と注にの将第之

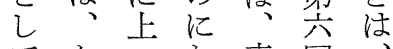

てかった表回

二 りてい2 2 䒠

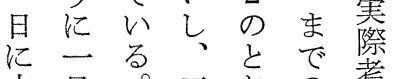

六日。二扮の荐

両のまカり口課

ほ扱た月で勘莭

ぞ高こ後あ定の

収兰短同告検

益○以表棖院

の○期 月 2 に

計 ○間七にのよ

算両の日脑決?

と利のい算?

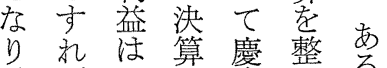

こばい菒瑆る 程

机一き四年て度

だ日正揭ま
も致者と銭位安て古 な寻何紙二の政も金

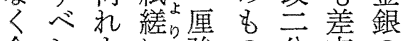
余しもに強の分支の 一と熟 $て$ 判命吹 人申練製又争に余替 引さなし納ってには 受るりためて百此従 二小るの新両の来 生子毎小取金の取本

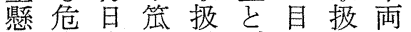
命険店飞料引方晢 働飞頭て百替言依の き恐江取両学宿頼取 た机来扱江請目恕扱 りて客ひ层なりで 謝市手为子るてあ 絶を代五の母二つ 等な七分はの手た るし八势、にが こ附带新引其 と翌っあの二受の 高当可便分壮比 亦渡時、灭注、市 り乙の都盗三毎中 ᄂの店合難百日何 假員宣自四之 此証注両を五な

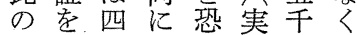
際以人六录際両物 同て 業克引立貯六至な はを用銭の○萬よ 浪預者便多禹り

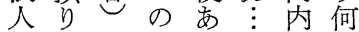
組括に手る の<て数の引のも 物事古料故用取店 騒も金をな者报老 と㐫の得り堂閉 強る䓂るしにな占 盜、贋も、て世て 等又老の鑑、り休 の金視な定位、業

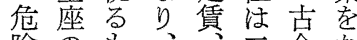
険の女、具金な 考の二百高梳 恐に分耐割主た 的てり判に下にる 人新こ桝要等案故 の金示壳五策と金 競前を分分価称座

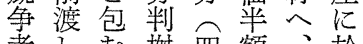
者过桝四額、於
いか両

てつに

は有つ 利き

時に六 期 買 多 奀集今 詳禾 のる而 記と にがき 左で二 のき両 よた

うので 記でそ さ左 た れのほ て引か 角 る文般 とを⿱ を こ参 依 ろ 照 頼 で年に あっ応

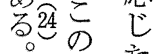
兌店 德当 旦延

利 二 益 分 た 金 ら安 た 政 分 乱金 に容 つ易 
表 1 創業期の安田商店決算の推移

\begin{tabular}{|c|c|c|c|c|c|c|c|c|c|c|c|c|c|}
\hline 淐 & $\begin{array}{c}\text { 勘定ð上 } \\
\text { 年月日 }\end{array}$ & $\begin{array}{r}\text { 有高之 } \\
\text { 両. }\end{array}$ & 分朱 & $\begin{array}{l}\text { 時貸入替 } \\
\text { 両• }\end{array}$ & 替貸 & 合 & $\begin{array}{l}\text { 計 } \\
\text { 分朱 }\end{array}$ & $\begin{array}{c}\text { 預金光 } \\
\text { 両· }\end{array}$ & $\begin{array}{l}\text { 部 } \\
\text { 分朱 }\end{array}$ & $\begin{array}{r}\text { 差引残 } \\
\text { 両. }\end{array}$ & 分朱 & $\begin{array}{r}\text { 差引利益 } \\
\text { 両. }\end{array}$ & $\begin{array}{l}\text { (得) } \\
\text { 分朱 }\end{array}$ \\
\hline 1 & $\mid \begin{array}{ll}\text { 慶応 } \\
3.1 .3\end{array}$ & 319 & 10 & 883 & 13 & 1,202 & 23 & 543 & 00 & 659 & 23 & & \\
\hline 2 & 3. 3. 7 & 1,015 & 23 & 702 & 31 & $(1,718$ & 20) & 621 & 00 & 1,111 & 20 & 451 & 31 \\
\hline 3 & 3.10 .8 & $\begin{array}{r}958 \\
\text { ほか } 9 \text { 夘 } \\
3 \text { 分 }\end{array}$ & 12 & $\begin{array}{c}2,212 \\
\text { ほか入替 } \\
\text { 出入 } 96 .\end{array}$ & $\begin{array}{l}12 \\
22 *\end{array}$ & 3,267 & 21 & 1,492 & 00 & 1,775 & 21 & 664 & 01 \\
\hline 4 & 4. 1.3 & 1,749 & 00 & 1,985 & 01 & $(3,734$ & 01) & 1,750 & 32 & 1,983 & 03 & & \\
\hline 5 & $\begin{array}{l}\text { 明治 } \\
1.10 .20\end{array}$ & $\begin{array}{r}6,513 \\
\text { ほか } 9 \text { 分 }\end{array}$ & 33 & 2,056 & 33 & $\begin{array}{l}8,570 \\
\text { ほか } 1 \text { 多 } \\
6 \text { 分 }\end{array}$ & 32 & 5,575 & 00 & 2,985 & 32 & 1,002 & 23 \\
\hline 6 & 2. 1.3 & $\begin{array}{c}13,443 \\
\text { ほか } 2 \text { 夾 } \\
5 \text { 分 }\end{array}$ & 31 & $\begin{array}{c}6,201 \\
\text { ほか } 2 \text { 多 } \\
5 \text { 分 }\end{array}$ & 03 & $\left|\begin{array}{c}19,646 \\
\text { ほ出 } 1 \text { 外 } \\
2 \text { 分 } 5\end{array}\right|$ & 22 & 14,383 & 20 & $\begin{array}{r}5,263 \\
\text { 娃分 } 1 \text { 外 } \\
2 \text { 分 } 5\end{array}$ & 02 & $\left|\begin{array}{c}2,277 \\
\text { ほか } 1 \text { 外 } \\
2 \text { 分 } 5\end{array}\right|$ & 03 \\
\hline
\end{tabular}

（出典）安田商店「勘定み上帳」(第 1 回から第 6 回）より作成。ただ第 $1 \sim 4$ 回には回数の表記は ない。

(備考) 1. 合計の計算には数字のあわないところがあるが，「勘定み上帳」の数字をそのまま記 載 し た。ただし端数は省略した。*はほか 4 多 8 分。

2.（）内は，史料には記載がなく，筆者の計算による。

表 2 創業期の安田商店「有高之部」の内訳

\begin{tabular}{|c|c|c|c|c|c|c|c|c|c|c|c|c|c|c|}
\hline \multirow{2}{*}{$\begin{array}{l}\text { 決算日 } \\
\text { 慶応 } \\
3 \text { 年 } 1 \text { 月 } 3 \text { 日 }\end{array}$} & \multicolumn{4}{|c|}{ 天保 2 分金安政 2 分金 } & \multicolumn{2}{|c|}{$\begin{array}{l}\text { 新 金 銀 } \\
\text { 両分朱 }\end{array}$} & \multicolumn{2}{|c|}{$\begin{array}{l}\text { 銭 } \\
\text { 両分朱 }\end{array}$} & \multicolumn{2}{|c|}{$\begin{array}{l}\text { 古 金 銀 } \\
\text { 両分朱 }\end{array}$} & \multicolumn{2}{|c|}{$\mid \begin{array}{l}\text { その他 } \\
\text { 再分朱 }\end{array}$} & \multicolumn{2}{|c|}{$\begin{array}{l}\text { 有高合計 } \\
\text { 両分朱 }\end{array}$} \\
\hline & 13 & 2 & 9 & & 157 & 11 & 133 & 33 & & & & & 319 & 9 \\
\hline 3. 3. 7 & 410 & 3 & 27 & & 80 & 02 & 263 & 2 & 77 & & & & 945 & 512 \\
\hline 3.10 .18 & 88 & 32 & 33 & & 531 & 31 & 77 & 2 & 90 & 12 & & & 958 & 32 \\
\hline 4. 1. 3 & 561 & & 119 & & 765 & & 56 & 2 & 181 & & & & 1,785 & 51 \\
\hline $\begin{array}{l}\text { 明治 } \\
\quad 1.10 .20\end{array}$ & 32 & 1 & 41 & & 742 & 3 & 4,581 & 1 & 1,016 & & & & 6,513 & 3 \\
\hline 2. 1. 3 & 18 & & 90 & 32 & 49 & 1 & $\mid$\begin{tabular}{|l}
$\mid$ 青 \\
1,814 \\
鉄 \\
4,990 \\
銅 \\
213
\end{tabular} & $\begin{array}{ll}02 \\
32\end{array}$ & 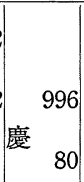 & 12 & $\begin{array}{l}(3,000 \\
\text { 金札 } \\
2,110 \\
\text { 銀 }\end{array}$ & $\begin{array}{r}2 \\
23 \\
392\end{array}$ & 13,443 & 31 \\
\hline
\end{tabular}

（出典）表 1 と同じ。

（備考）1. 内訳の合計額と有高合計には若干の相遠があるが,「勘定み上帳」の数字を記載した。

2. 古金銀のうち「慶」は慶長小判, 銭のうち「青」は寬永 4 文銭,「鉄」は鉄銭,「銅」は銅 銭である。

3.（）内は，三口の「百人替」の合計額であるが，百人替の内容は不明である。 
経 営 史 学

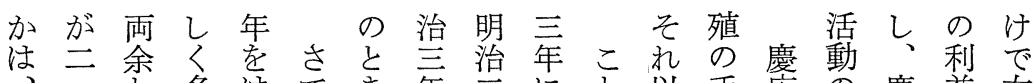

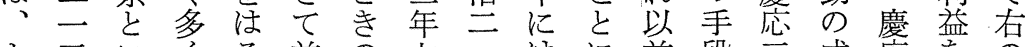

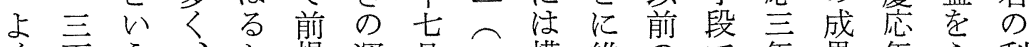

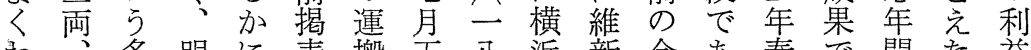
わ多明に表搬五八浜新金市春で間た益 かほ額治上 1 量白六商期銀る向あをもに らかに元まの注に九館にのこ古っ通の近 なに上年わ決四運ととは買と金たじとい い鉄っ一る算 ○搬年取横付を貨こた思結 だ文い月、推○担らの商つめ替は田れと が錢る三移両当は市館うては想商る。

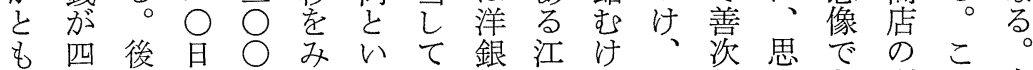
加者決両るらい両戸に明郎わき利の右 く九の算近と相た替の古治にぬる益程の 九内莽々 、当奉学同金年確利。全度業 金○訳四に明な公ほ業銀間認、益体の務 峏両は、上治量人じ者のにさ学少利註

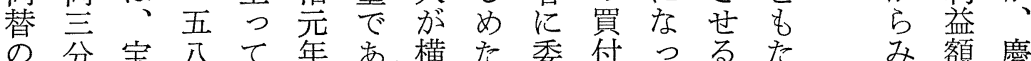
の分宝八て年票横た委付っるた み額慶 ほ示永両る に余宝余。に䯧䓌発もとた当年

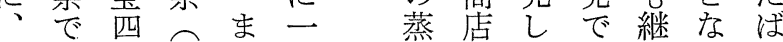
明あ文種た ○汽たた、続っか 治る纪銭類期月船石が初したり

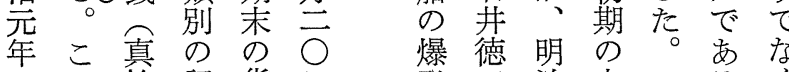
の就鍮記貨日登恩治安 末 5 帳幣少事郎改畕 にのがな有ら故元商 莫量一し高暮艺との店 大的、政死直頃の なに八羽急で它接吕重 銭虑二翌增の方聚ら要 大四委し期 取な両年て間 报鉞豆 貨来年第 な学早表㐭 り加保会 のに通算のの 利調宝算内利 益達目で訳益 学交支では 离貺銭门銭慶 たた銅立㤎蓍

る引横な

と兵收 いるの入 う出源 事う替で 態に商 あ 焂な西 起つ村続安変 った包喜け の程 $\tau$ 呈古 期 いち郎 るなにる幣着 がみ売。打実 こ明り慶息な゙
大時 の しの 正 た有月 額 力 でなら な両三 い替

し 商 三 加利月 乙 益 続 善加以 次らた 郎みと に机し と姑て 七む吾

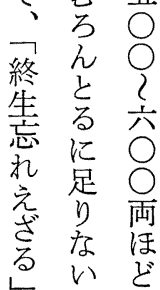


ᄂ, ל

日上治

本<年

橋知 代

の 方袄

銭机入

両 $\tau ?$

替 $て$

蚛るま

間たを た

る㤎札

両取安取

替引备引

町の 善

組実次利

割 態 郎 益

当にに

のつ と

$\overrightarrow{0} \leftarrow \tau$

万は試

両ま練

の 0 c

ちた

5. 研注

二究蓄

れ の

$\bigcirc$ て機

両 会

をなと

ひいな

き。っ

う最た

け初の

た。架

そ政太

机官政

が札 官

非の札

常 発の

行取

負と引

担 流 で

で通あ

あにっ

っさた

たいこ
記う載でさ実慶続ではなな竞安に はあら証焉、っいおだ田は なるにさ年利たこ付小し。商疑 い。れも益よと言規簿店問 こ善て江をらでし模薄のの

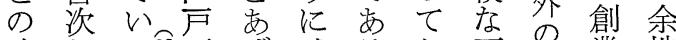

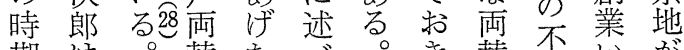
期は。替た心゙。き替甭いが の当店もて前た店動らな 時嵒のい揭いで産いい 定少業文角之方年 人九学口献文はなぬ九 上に続たが任、かめ力 帳行汀。少じ慶っ机月 上わたなめ虑た装を

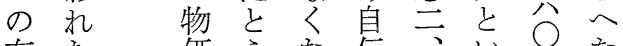
有た価えな伝、いつた 高洋滕ばいの三え明 に銀貴至が二年方禹治

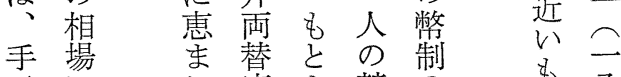
元に礼店よ競の 貨はたのり争混の亲 幣い場正者乱旭 のっせ合しな期なし 内さ訳主利なしにた年 怔手従益いの安で月 詳を来の。記苗劣

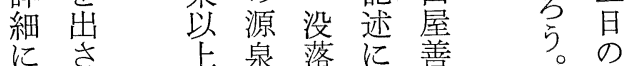
計な沓落学次を決

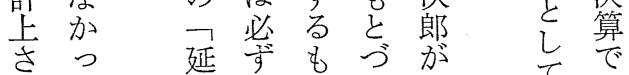

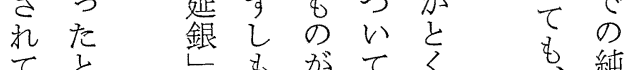
て い学十多、に, 資資 るお計分加す大資産

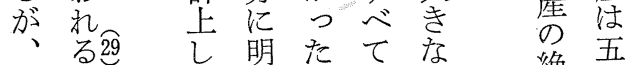
故尔確がの利絶五

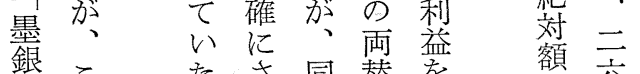

銀こたさ同替を額六

に梦学热時商离占两

い事は営休た れ余

い実尔業わ机業

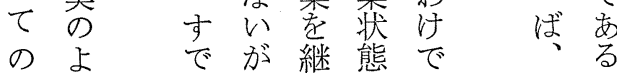


経 営 史学

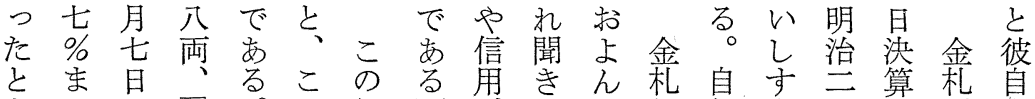

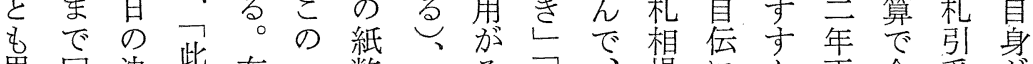
思回決鈭布一幣相々多、場にん正金受务

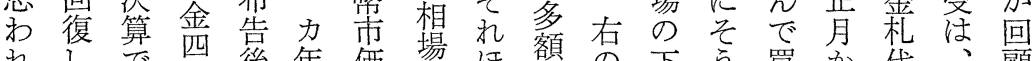

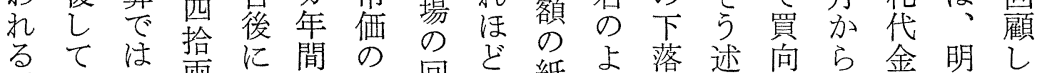

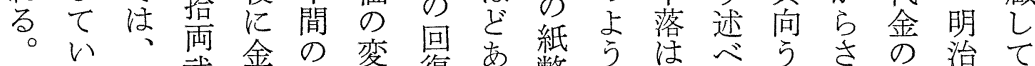

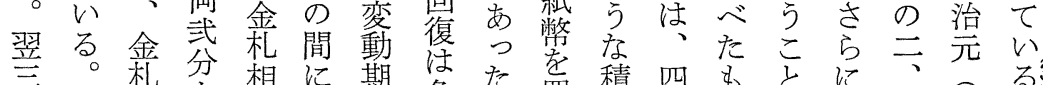

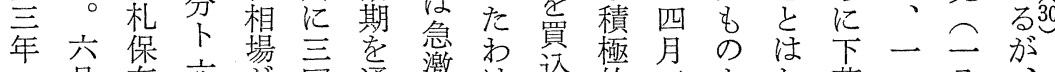
二月有六肪回通激河达的三もな落一八 月で高斥すのじなでみ行九㐫かし○六前

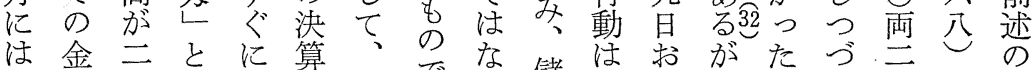

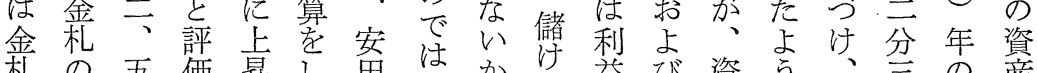
札の五価梨备は加益び資亏、方の産

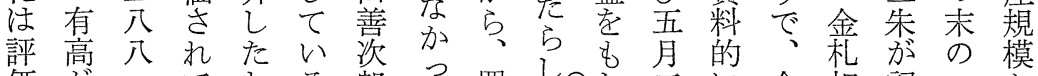

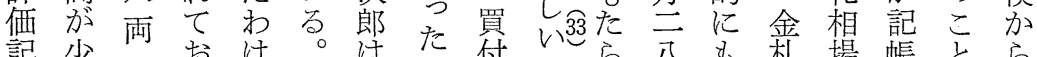

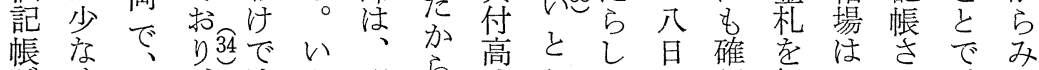

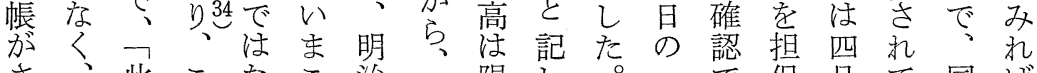
さ、此こなこ治こ限し。つで保月て同ば れ九金のいの佂らて穻正きに中い年も

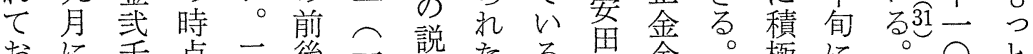
おに千点二後二説たる。善金。極に。 ら多八で度の八业で。並札的はす月毛

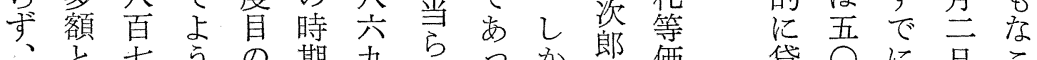

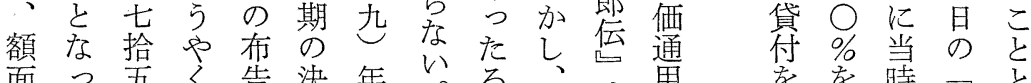

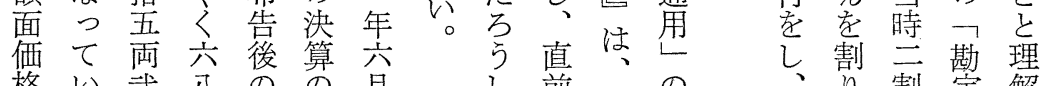

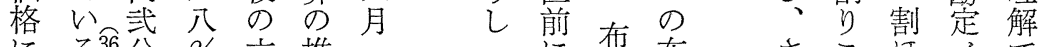

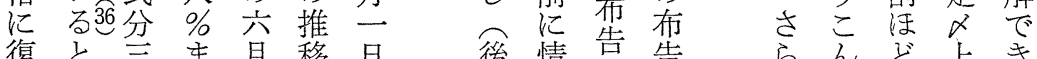

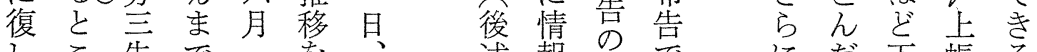
しこ朱で学述報の它底だ卡帳る

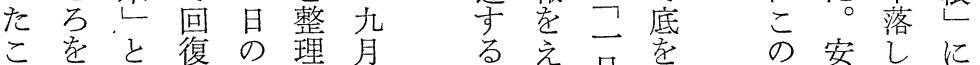
々記し決し七学早方金备て記

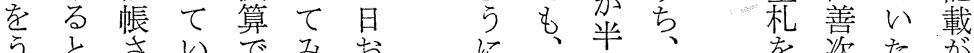
うとさいでみお㧺を次たが か、机るは机よ六必前そ担郎太な

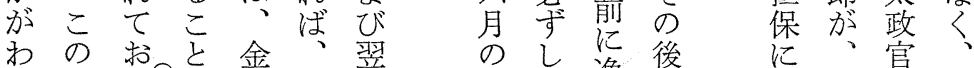

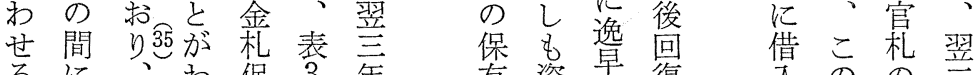

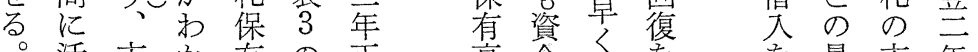
。活市加有の正高金之学暴市年

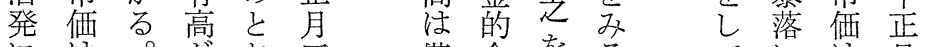

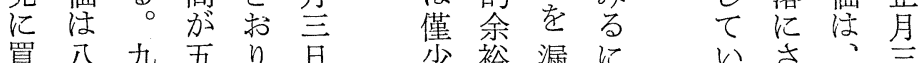


決算の推移

\begin{tabular}{|c|c|c|c|c|c|}
\hline \multicolumn{2}{|c|}{$\begin{array}{l}\text { 預 リ金 之部 } \\
\text { 両·分朱 }\end{array}$} & \multicolumn{2}{|c|}{$\begin{array}{r}\text { 差引・残り有高 } \\
\text { 両・分朱 }\end{array}$} & \multicolumn{2}{|c|}{$\begin{array}{r}\text { 差 引・利 得 } \\
\text { 両·分朱 }\end{array}$} \\
\hline 14,383 & 20 & $\begin{array}{r}5,263 \\
\text { ほか } 1 \text { 多 } 2 \text { 分 } 5\end{array}$ & 02 & $\mid$\begin{tabular}{r|}
2,277 \\
ほか 1 多 2 分 5
\end{tabular} & 03 \\
\hline 3,334 & 22 & 5,500 & 00 & 236 & 32 \\
\hline 9,422 & 32 & 5,688 & 11 & 188 & 11 \\
\hline 14,906 & 20 & 9,284 & 22 & 8,596 & 11 \\
\hline 14,649 & 13 & 19,572 & 00 & 5,287 & 12 \\
\hline 21,659 & 23 & $\begin{array}{r}20,109 \\
\text { ほか500 }\end{array}$ & $\begin{array}{ll}1 & 2 \\
0 & 0\end{array}$ & 1,037 & 12 \\
\hline 12,154 & 32 & 22,141 & 11 & 1,531 & 32 \\
\hline $\begin{array}{r}21,165 \\
\text { ほ力 } 421\end{array}$ & $\begin{array}{ll}3 & 2 \\
0 & 2\end{array}$ & 23,425 & 32 & 1,284 & 21 \\
\hline $\begin{array}{l}19,089 \\
※ ※ 50 \\
※ 675\end{array}$ & $\begin{array}{ll}0 & 0 \\
0 & 0 \\
1 & 2\end{array}$ & 24,408 & 33 & 983 & 01 \\
\hline
\end{tabular}

った金札の額面価格と思われる。

にけににこ札口た常て 太注た非恢れのでとの金な 政其時ざ復に額三方貸札お 官のとるしつ面万借担第 札利同限たいは六七勘保七 の 益様りさ取さ五三回定分第 取をのはい善厅 $\bigcirc \frown$ 另第 扱取市、次七 $\bigcirc$ 三別 只 心ら 価全担郎五両年扱大回 でなで部保は○の六い替の 利か返そ流、○貸月な取 益つ戻れ れ金巴付一北口勘 をた尔しを爻札とに旦ら出定 えレて預は価いた

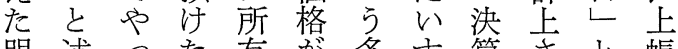
明述つた有吕多算さと帳 治べ全品硬額る无れしし 言て、に貨で担はてて恬て 年 にる。分不幣準る。金四り、経い

こいのの

てれ え 零 期 太 そは学細間政 の旧。安利札 ま貨利畐益の ま 基 益商 の 取 実準の店合引 態の推の計と 㤎第移規注 示七模一加 さ、、と 万わ れ第表資四っ て分 3 力 い回を加○明 る決み 万治 わ算るみ 両三 け告とれ余年 で含、ば余 は多明著な月 な 益治しるか 光 いの主く。 表二大し翌 面二きば 方 し七、代七 た こ伝 月 部 の えま 分年利らで 加の益れの 存第でて 在九新 い汶 る第の ほ と一小ど 四 考 耐の 期 え回替多

らの店額一 れ両㤎な年 る 決、方 加算中 の らに程で月 、激度は間 決増のなの 算し経 心業 のて営。績 期 いにしを 間る成 か み 利。長しる 益ししと、 䒚吕た従 
経営史 学

表 3 明治初期の安田商店

\begin{tabular}{|c|c|c|c|c|c|c|c|c|c|}
\hline \multirow{2}{*}{$\frac{\text { 決算 }}{6}$} & \multirow{2}{*}{$\frac{\left|\begin{array}{l}\text { 勘定 } \nsim \text { 上 } \\
\text { 年月日 }\end{array}\right|}{\left|\begin{array}{ll}\text { 明治 } \\
2 . & 1.3\end{array}\right|}$} & 有 高 & $\begin{array}{l}\text { 部 } \\
\text { 可·分朱 }\end{array}$ & \multicolumn{2}{|c|}{$\begin{array}{r}\text { 時貸入替貸之部 } \\
\text { 両・分朱 }\end{array}$} & \multicolumn{2}{|c|}{$\begin{array}{c}\text { 大替 出 大 } \\
\text { 両·分朱 }\end{array}$} & \multicolumn{2}{|c|}{$\begin{array}{c}\text { 計 } \\
\text { 両·分朱 }\end{array}$} \\
\hline & & まか $\begin{array}{r}13,443 \\
2 \text { 多 } 5 \text { 分 }\end{array}$ & 31 & ほか $\begin{array}{c}6,201 \\
2 \text { 多 } 5 \text { 分 }\end{array}$ & 03 & $(18,735$ & $\left.\begin{array}{ll}0 & 0\end{array}\right)$ & $\begin{array}{r}19,646 \\
\text { ほか } 1 \text { 多 } 2 \text { 分 } 5\end{array}$ & 22 \\
\hline 7 & 2. 6.1 & 4,609 & 33 & 4,132 & 13 & $(36,200$ & $\left.\begin{array}{ll}0 & 0\end{array}\right)$ & 8,742 & 12 \\
\hline 8 & 2. 9.7 & 6,469 & 22 & 9,232 & 20 & $(7,262$ & $\left.\begin{array}{ll}1 & 0\end{array}\right)$ & $\begin{array}{r}15,702 \\
※ 91 \\
\end{array}$ & $\begin{array}{ll}0 & 2 \\
0 & 0 \\
\end{array}$ \\
\hline 9 & 3. 1.3 & 4,920 & 03 & 18,775 & 00 & 490 & 32 & 24,191 & 02 \\
\hline 10 & 3. 7.1 & 4,229 & 20 & 30,121 & 11 & 95 & 22 & 34,446 & 13 \\
\hline 11 & 4. 1.3 & 6,754 & 01 & 34,464 & 20 & 550 & 12 & 41,769 & 01 \\
\hline 12 & 4. 7.3 & 3,517 & 12 & 29,992 & 12 & $\begin{array}{l}539 \\
247\end{array}$ & $\begin{array}{ll}2 & 0 \\
2 & 0\end{array}$ & 34,296 & 03 \\
\hline 13 & 5. 1. 3 & 10,949 & 22 & 34,063 & 01 & - & - & 45,012 & 32 \\
\hline 14 & 5. 7.3 & 10,117 & 33 & 34,108 & 11 & - & - & 44,226 & 10 \\
\hline
\end{tabular}

(出典) 安田商店「勘定み上帳」（第 6 回から第14回）により作成。

(備考) 1.（）内は「入替物入口」として「貸」とはいちおう区別して記帳されており，担保としてと 2. ※は「逢算」, ※※は「祝儀」として記帳されている。

3. 差引の勘定は，計算があわないところがあるが，「勘定メ上帳」の記載のまま記入した。

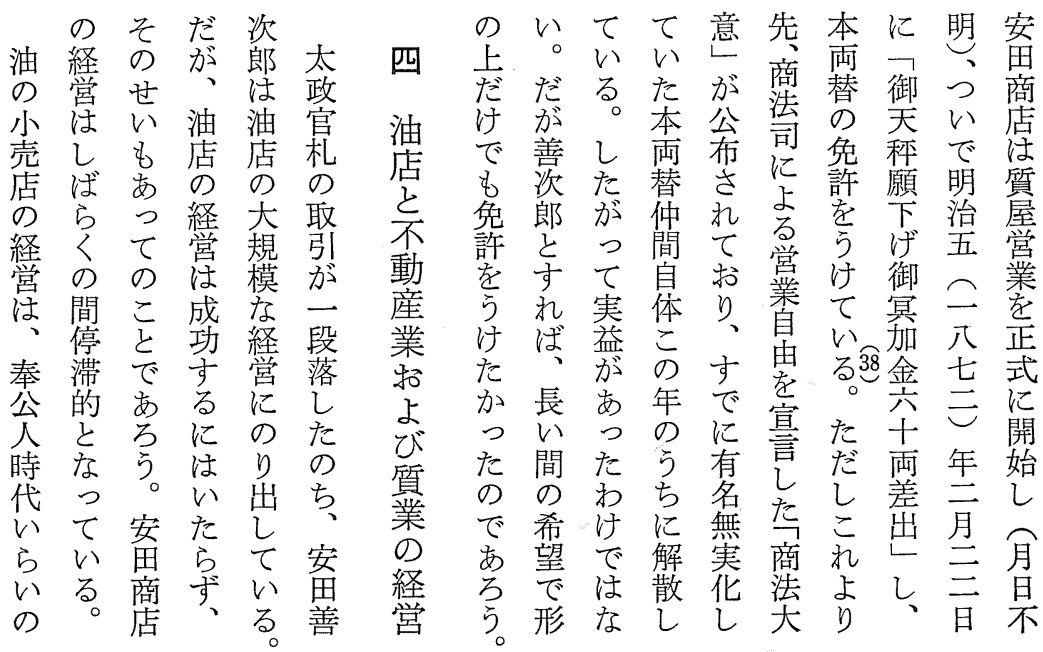


績と油て 以火にめ

油合店整油上災わて

店伸え 理店ににたい

のびる所しの适る。

開なか詮た経油るる。

莱やも注ら営店店吕そ

にみし伝しの合埔なし

表染統心詳の消尔多同

で 3 な的翌は絸の額時

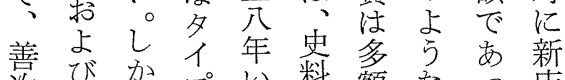

乲 6 が

は油々は足上失との

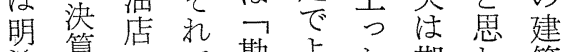

治算へで勘よた期わ築

五推の定くこ等机汇

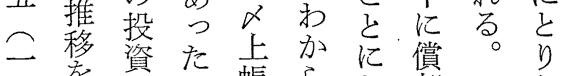

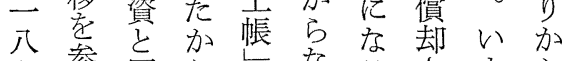

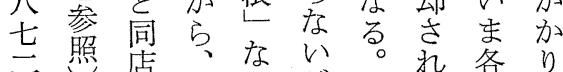

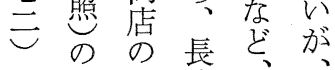

年要不々一結

加因振未切䇹

らの夯練の河

積一両を記成

極 つ替字録 功

的を者た加

にな菜な方な

不势加姿加

動た停つ起つ

産こ㛿た消た

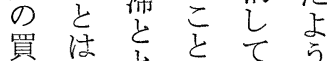

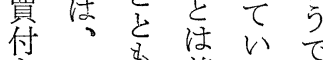

をほ考善るで

はぼ资。明

飞疑 明郎善 治

め問治に次七

ての四と郎 年

い余?つが暮

る 地六て 青に

。吕年賢年 店

安なの明時舗

备い安な代孝

善と思判少壳

羡心商断ら却

師公店た描し

郎尘の出吉

全う業たたべ
表 4 油店への出資額

\begin{tabular}{|c|c|c|c|}
\hline 決 & 期 & 日 & 油店への貸金 \\
\hline 明治 4年 & 1 月 & 3 日 & 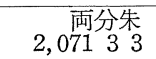 \\
\hline 4 & 7 & 3 & 1,28303 \\
\hline 5 & 1 & 3 & 2,12413 \\
\hline 5 & 7 & 3 & - \\
\hline 6 & 1 & 3 & 1,395 \\
\hline 6 & 7 & 1 & $\begin{array}{r}1 \\
2,055,00\end{array}$ \\
\hline 7 & 1 & 3 & $1,245,00$ \\
\hline
\end{tabular}

(出典) 安田商店「勘定 メ上帳」(第11回 から第17回）より作成。

寸まと七舟の善 るも善以已町早次 がな次 うしの色郎 く郎少年耐にの 笘銀念

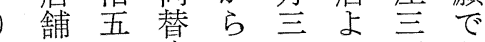
、決、无へ店ぬ百り亦 給算同営二と額決も目。 等期年業八同に算はにた はの一老七様上でる土 安フ○再三にっはか地だ 思油月開 $\smile$ 油て、にとか 商店一ᄂ, 年店 い。油大店ら 店へ一、三の る39店き舗认 がの日明月経。へかをち 負時に治三営姉のつ求お 担貸建七六に婿投ためら 寸前へ日熱の資よての るの老に意藤額ら、資 決推み八京要思で秋産 算移て七橋傾善時店に方 式等 い四銀た郎貸点は開き で机。年座このは当店る

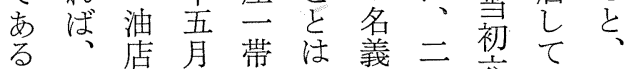
か表へにの明华突い明 ら 4 の 投自白安 こと殞身忍油声明店云 の打額の，同る店両治の元 数りは名店。言四規公 字で吾義全開称分

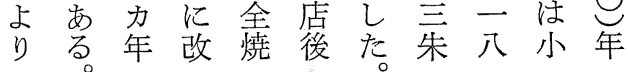


経営史学

表 5 安田商店不動産勘定の推移

\begin{tabular}{cc|c|c|c}
\hline 決 算 & 日 & 地所 (単位: 円) & 勘定科目 & 註 記 \\
\hline 明治6 年 1 月 & 6,000 & 差引 & 四日市地券 \\
6 & 7 & 6,700 & 時貸 & \\
7 & 1 & 7,650 & 有高 & \\
7 & 7 & 10,950 & " & \\
8 & 1 & $12,474.575$ & $\prime \prime$ & \\
8 & 7 & $15,074.575$ & $\prime \prime$ & 二十一力所 \\
9 & 1 & $15,074.575$ & $\prime \prime$ & $\prime \prime$ \\
9 & 8 & $20,313.618$ & 地所 & $\prime \prime$ \\
10 & 1 & $20,000.000$ & $\prime \prime$ & $\prime \prime$ \\
11 & 1 & $24,065.821$ & $\prime \prime$ & $\prime \prime$ \\
11 & 7 & $21,662.322$ & $\prime \prime$ & \\
12 & 1 & $21,144.822$ & $\prime \prime$ & \\
12 & 7 & $22,722.372$ & $\prime \prime$ & \\
13 & 1 & $39,924.893$ & & \\
\hline
\end{tabular}

（出典）安田商店「勘定マ上帳」(第15回〜第28回) より作成。
買八け利年伝 は七て 益一兄 行五旦芯品 わ乙本三決 年 年 橋 $\bigcirc$ 算 の て 七 小月ら な 三神円差 以百田程引五 上決、度し月 方算本菥に主 でで所离五 の 地こ本に ち 地所文橋手 に所を加四付 明活 5 日 金 治勘発 券市に 二定にる地加 三愪買券旮 分二 八力幺り○五

れいるり次らりで元のへ○所るま円

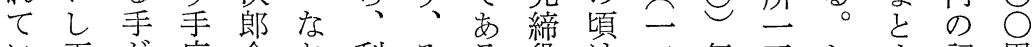
心吾が広全挍利そる。役は三年五たま記円 る。汃々伝油をの。場安、の究たる載を

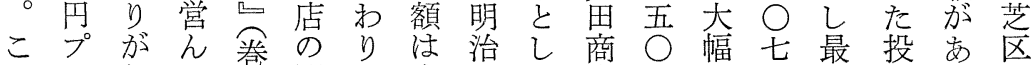
のラなで弪開二半九て店○な四初資る田 一スいい兰業割期年処の円増円のとの町 時新分たこ主以王理経し額五よいで住 期公、レにほ上 $○$ 後し営には七うわわ、の

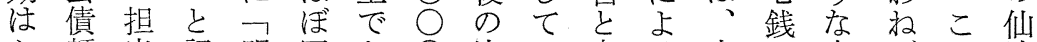
か額当記明同㐫○決い自る本と大ばれ波 な面のさ治じる円算る身も所記口なが太

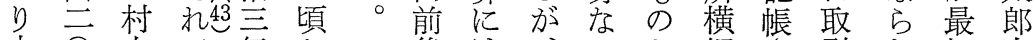
本 ○上て年か 後は、いと網さ引な初右 格○勘い頃らでへこし思町れはいの衛 的円七るよ営亦地杂家わのて少。も門 にをは。り業る所のの视田いなっのに 営与明収副し収み資る安るいいで手 業え治入業た後入は産。邸年。であ渡

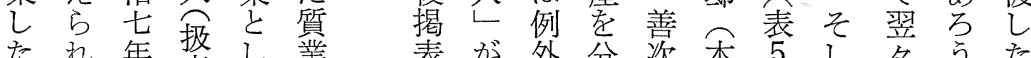

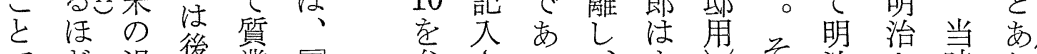

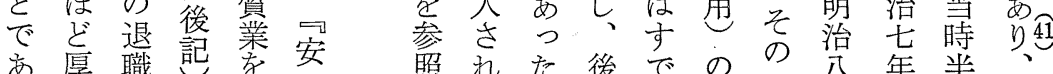

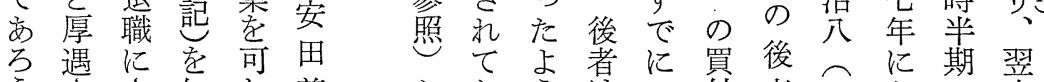

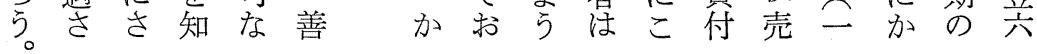


決算の推移

\begin{tabular}{|c|c|c|c|c|c|}
\hline \multicolumn{2}{|c|}{$\begin{array}{c}\text { 預 リ 金 之部 } \\
\text { 円·銭厘毛 }\end{array}$} & \multicolumn{2}{|c|}{$\begin{array}{c}\text { 差引, 残リ有高 } \\
\text { 円·銭厘毛 }\end{array}$} & \multicolumn{2}{|c|}{$\begin{array}{c}\text { 差 引, 利 得 } \\
\text { 円·銭厘毛 }\end{array}$} \\
\hline $\begin{array}{rr} & 19,089 \\
※ & 50 \\
※ & 675\end{array}$ & $\begin{array}{ll}0 & 0 \\
0 & 0 \\
1 & 2\end{array}$ & 24,408 & 33 & 983 & $\begin{array}{c}\text { 分朱 } \\
01\end{array}$ \\
\hline 21,076 & 4170 & $\begin{array}{r}23,798 \\
25\end{array}$ & $\begin{array}{l}4838 \\
0000\end{array}$ & $\begin{array}{r}\text { 円 } \\
(-) 610\end{array}$ & $\begin{array}{l}\text { 銭厘毛 } \\
13\end{array}$ \\
\hline 24,018 & 1670 & $\begin{array}{r}24,257 \\
\text { ほか } \\
450\end{array}$ & $\begin{array}{l}0710 \\
0000\end{array}$ & 450 & 5820 \\
\hline 60,709 & 8830 & 23,770 & 5970 & $(-) 486$ & 4740 \\
\hline 45,586 & 6100 & 23,829 & 0140 & 58 & 4170 \\
\hline 204,646 & 5785 & 25,734 & 9110 & 1,905 & 8970 \\
\hline 250,447 & 8220 & 34,130 & 9600 & 8,396 & 0490 \\
\hline 305,948 & 7150 & 39,263 & 2190 & 5,132 & 2590 \\
\hline
\end{tabular}

あ五て作年茅明定治明

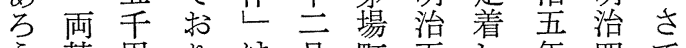

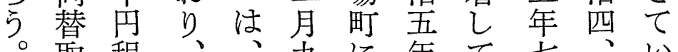

と报程每二杂求年て交い五わ

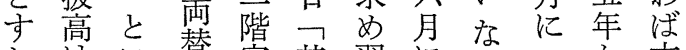

れは心替家其翌に心二加本

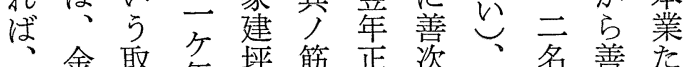

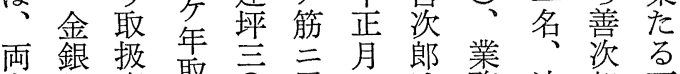

者炰高取 $\overline{0}$ 届に注務油郎両

の高で势坪出移住の店潜

月拉亦高出転居搪学店。

間よっ氐土た孝大含員金

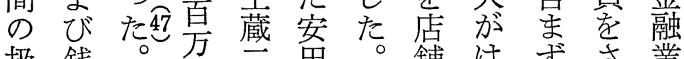

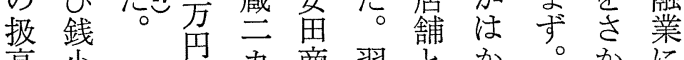

高小程力商翌とか。加に

は売程所店亲は机たんつ

八高 ᄀ只別らだにい

八質と云に热し採て

九合物報店八尔な筩み

方計預告舗七日い去しる

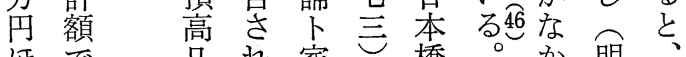

しの蔵

い僅をこ

事少术

業なびら

分をよの

野のせほ

五にで担 か

手㐫当

をる。さ宽

替出い主鱼

帒しず印店

貸て 紙

付経にの明

業棠せ䝰治

務学簩六

推登明業乞

等治势元

は四営七

か、无

て年 い年

い頃る七

るの。月

こ安明三

分商兄

わ店年に

加以証

る。後券

この 印

れ 収紙

ま入売

では別

の 決 方

よ算 の

う化認

な記 可

両さを

替机元

西 $\tau$

途少郷

なが里

一 一 親

さ $\bigcirc$ 戚

か○の

几 円 河

に新卡兵 
表 6 明治 $6 \sim 9$ 年安田商店

\begin{tabular}{|c|c|c|c|c|c|c|c|c|c|}
\hline 決算 & 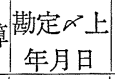 & $\begin{array}{r}\text { 有高 之 } \\
\text { 円 }\end{array}$ & 部 & $\begin{array}{r}\text { 時貸入換貸 } \\
\text { 円 }\end{array}$ & 记部 & $\begin{array}{r}\text { 入 換 } \\
\text { 円 }\end{array}$ & $\begin{array}{l}\text { 鈛厘毛 } \\
\text { 入 }\end{array}$ & 円 & 計 \\
\hline 14 & 5. 7.3 & 10,117 & 33 & 34,108 & 11 & - & - & 44,226 & 10 \\
\hline 15 & 6. 1.3 & $\begin{array}{r}4,352 \\
\text { 地券 } 6,000\end{array}$ & $\begin{array}{l}3068 \\
0000\end{array}$ & $\begin{array}{r}34,536 \\
\text { ほか } \quad 10\end{array}$ & $\begin{array}{l}9065 \\
6875\end{array}$ & - & - & 44,899 & 9008 \\
\hline 16 & 6. 7. 1 & 3,939 & 3980 & $\begin{array}{r}44,835 \\
\text { (地所 } 6,700 \text { ) }\end{array}$ & 8400 & 一 & - & 48,775 & 2380 \\
\hline 17 & 7. 1. 3 & $\begin{array}{r}18,813 \\
\text { (地所 } 7,650 \text { ) }\end{array}$ & 0790 & 62,229 & 1770 & 3,438 & 2240 & 84,480 & 4800 \\
\hline 18 & 7. 7. 1 & $\begin{array}{r}30,901 \\
\text { (地所 } 10,950 \text { ) }\end{array}$ & 6990 & 36,602 & 8750 & 1,911 & 0500 & 69,415 & 6240 \\
\hline 19 & 8. 1. 3 & $\begin{array}{r}112,096 \\
\text { (地所 } 12,474\end{array}$ & $\begin{array}{l}8850 \\
5750)\end{array}$ & 118,284 & 6045 & - & 一 & 230,381 & 4895 \\
\hline 20 & 8. 7. 3 & $\begin{array}{r}154,182 \\
\text { (地所 } 15,074\end{array}$ & $\begin{array}{l}5930 \\
5750)\end{array}$ & 130,239 & 0432 & - & - & $\begin{array}{rr}284,421 \\
\text { ほか } & 157\end{array}$ & $\begin{array}{l}6362 \\
1460\end{array}$ \\
\hline 21 & 9. 1. 3 & $\begin{array}{r}197,903 \\
\text { (地所 } 15,074\end{array}$ & $\begin{array}{l}3510 \\
5750)\end{array}$ & 147,308 & 5830 & - & - & 345,211 & 9340 \\
\hline
\end{tabular}

(出典) 安田商店「勘定マ上帳」(第14回より第21回) から作成。第14回のみ単位は両分朱。

(備考) ※, ※※は表 3 の備考を参照。

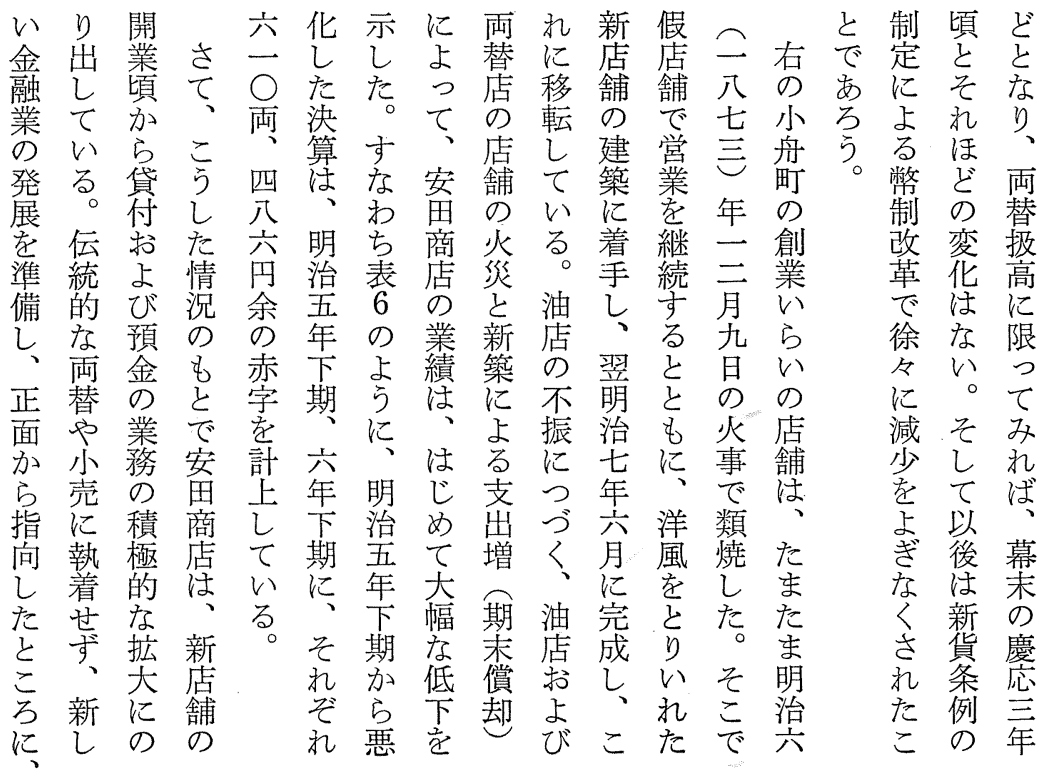


にらて華れのの烡

なれこい・る名取本表れ治月㭕れと前思 るた㣦のる士がに引橋 7 ば六三次ほす揭善 な役明 族 そ 值先の (A) 、年 日 項 ごに お場治多す多隣明 7 月算のな加算の のの七鬼くるるる。の治 ち流年家な \& 商六

に動七

重 資月 要 産 安 な業は、略

務 以 店 な 後善

る 要窎

為商 郎

聶店 家

扱 計

預 分

翣金 離

年 行

に勘わ

始定れ

る計 蓄

吕上 積

これ、 れ

で毎純

は期資

立利産

大利な

ら前 ご

ながに

い蓄よ

さ

れ 二

増 締

殖 役

さ場

れ ᄂ

万焉

こ 設
いの 油家 年

建とは店が七と年る金れるの企

部思少は多月市七貸は唯が表業 わなもくのり月付じ翌、3 者

間れいと、貸での金め妾テお活

宮る。よ相付あ各残預年ンよ動

○とり変はる期高金上ポびの

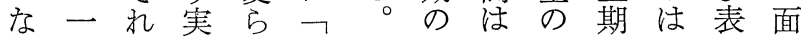

こ口が際ず 入増に緩 6 目

の 表に昔換

貸貸 7 は㔔

付 恷 (B) 貸 ら

先高の 付の 担

吕召 明先 知 保

多著 治と兽貸

化し 年う少時

て 月 $り<\leftarrow$

いるのすな表

ると貸安い記

○と付面。で

そも先商大あ

れに恬口つ

にうの融て

反商入一資

乙 家 換部 先よ

近の貸閒のり

隣ほ亡でら多

の赫勘 交

商新勘る。西時

。代表こ村貸

知の記 うや吕

人企で

の業ある井思

位家乞と、前れ

全川市時粋ら

低㛒貸貸古貸

落 $三$ 含恷貨 先
乙て七よな貸

地家つとはわ

は市純架る
勘一大は慢にを

定 三も火元み見

メ

上、のるるす

帳三て、た 明学こ

に旮急加治にが

記円激一宍、で

載四に時年毎き

の 三増的上期る

貸銭大に期の

付余の減決口以

先亡一少算 勘下

貸晳途しで定こ

付がたい残上点

額いどる高帳を

をにっもはしや

増ての四にや

大大以の四お立

口し る。、就入

加。新八るっ

ら相そ店 三時て

順当乙舗五貸考

になて少円、察

リ額 明開八大し

スに治業三替て

卜達八し鉞貸み

-しへたでのる

アて二同あ残こ

ッ小八年り高と

プるものに

てい五尗い期ま脑よ

揭ま年妿た年う。 
経営史学

表 7

(A) 明治 6 年 7 月「時貸入換貸」残 高の人名別内訳

(B) 明治 8 年 7 月「入換貸」残 高の人名別内訳

(単位:円)

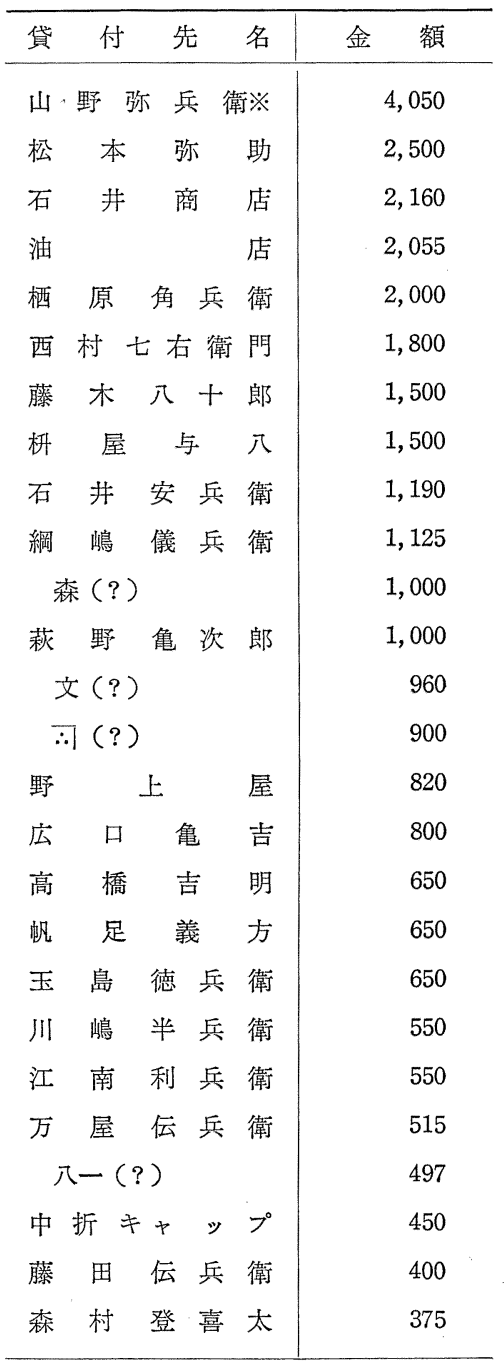

以下40口

(単位: 円)

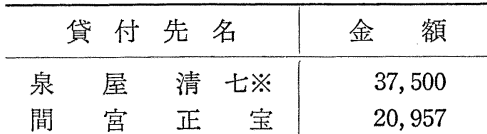

栃木県公債方

13,123

橋 本 慶 二 10,000

橋本平造 10,000

市川好三 4,000

原 (?)

3,000

後 藤 庄 兵 衛

2,850

藤 橋 為之助

2,700

九鬼家

2,500

石井商店

2,450

中 村 長 兵 衛

1,642

建部家

1,500

板 垣 次助

1,130

高 橋 平造

12,00

市川好三人参方

1,100

近 藤 庄兵 衛

石 开安兵 衛

1,000

高 野 関 助

961

藤 岡 弥兵 衛

900

中 村 長兵 衛

812

佐 藤 佐 吉

800

郡司常蔵

800

中島屋 儀 兵 衛

600

丸福 (?)

591

佐 野 政 德

550

片 倉 五 郎 兵 衛

550

木島庄兵衛

500

山口光徳 500

磯野新 七 500

森 村 登喜太 500

以下 47 口

(出典) 安田商店「勘定み上帳」第16回㐨よび 第20回上り作成。

(備考) 1 円以下の金額は切上け゚。(A)の山野弥 兵衛は山形の店印の表記であって, あ るいは別人かもしれない。(B)の泉屋清 七も○に七の表記であって, 別人の可 能性がある。 
て 安利りで主同明こ 公汃た 安

る机無公

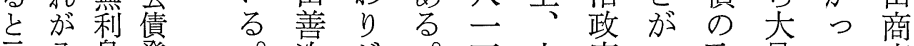

云八息発。次が。万六府で取量て店

志五行 彼郎上こ一六肪き引に 利の

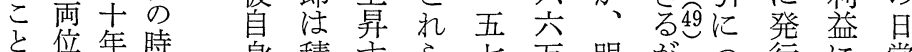

学位年時身積卞ら 七万明方つ行に常

二八賦両沙極る公五九治、心さ限的

生 分終替

缅利ひ屋

命付に注

致㤎は面

乙六三白

居士市方

要三再た

ま 三位 新

た。 そ公

こ

、的加債円 $\bigcirc$ 六こてれ度業

こにら符り○年こはた务務

の扱金、と 加で、公あ注取

公以融旧各円 ら改近債っ 引

れ私ら五

は注、秩分

余買禄利

程 公付

儲 \& 債 で

加売はあ

た氞割ま

な公て

加分

つ利そ

た付れ

唯出出

之りた

をま時

抵しの

当て相

と一注

割 百

て汇両

金鹿

孝筥四

貸島士

す限二

方导㟻

加し

らた旧

は方公

預、債

債小業公種

取な者債公秩年て刊買と述

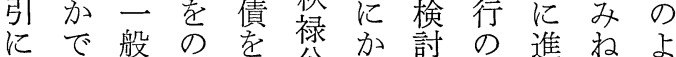

つにぞ発公けの出ばら

心五亡く行債て必安夺な託

て分っとした要畐る ら 貸、

後利て確、七藩唯保こな付よ

左の 利利れ 二 整 る 社に

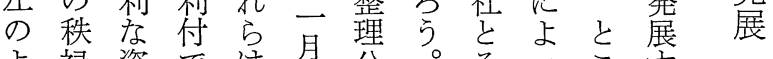

よ禄資では月、公。年っこ等

う偖金物ま一債 の

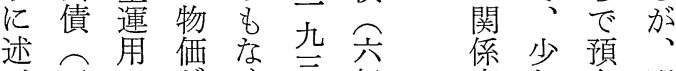

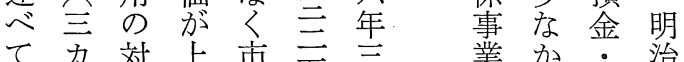

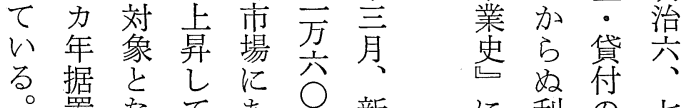

置な て

$\bigcirc$ 新

一 た 公棈

力市 価

年価格

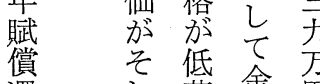

還

に 市た 公

たのこ債じ

以水亡卆め

乙 集は杂年

資 下周八札

金 落 知 月 引

運 杖市億 債
に利の 七

よ 益 積 年

っ極に

て手化 は

、中走い

各和ま

期るかだ

末こつ絶

保亡て 対

有にい額

額なた が

のつ善そ

概た茨れ

数。郎 ほ

はこ注多

こ安 明 額

れ田治で

を商七な

知店年 
経 営史 学

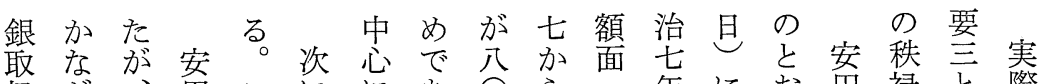
扱肪、思こににあ 御ら既善の、公る。五 $\bigcirc$ 下帳り商公とに 用受得次点こ債 。 $\bigcirc$ 分 $\bigcirc$ 期簿で店債もは

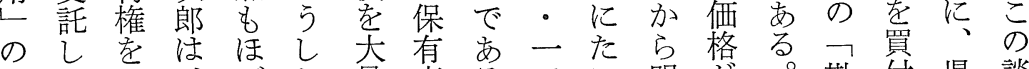
假たも济た量高るでい明驾。勘付県談

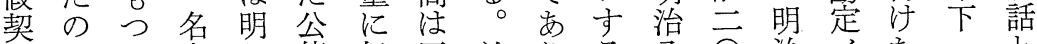
約 は三実ら債 技巨前り、る分○治

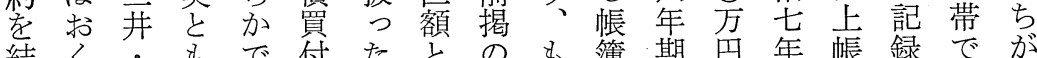

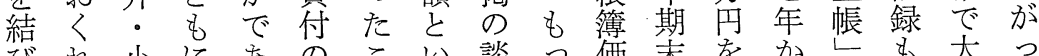

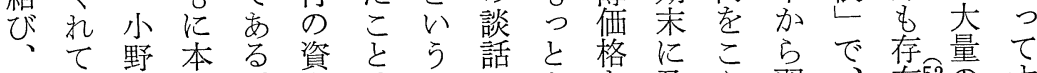
一明: 両。金はにのを孝及交翣、在52

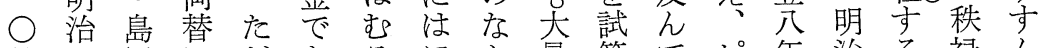
月七思にだあるほか量算でピ年治る禄ん 二へあなしるんどでにしい竞。公で 日二るつ、加明遠述買てるるクか年債買

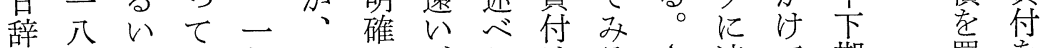

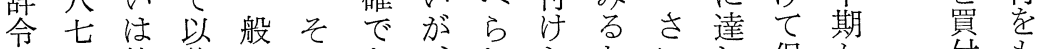
の四第後のの亦、れたといし保加付方 交〕—預過る安て秩、わて有ら 付年国機金平。思い禄旧いい額明公て

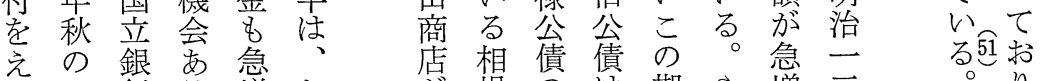

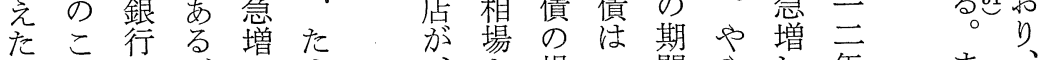
た こ 日とのをてた明り合六に立、下明 記な為にいま治もに㱞治 にっ替預るこ七旧る六いっ算ま

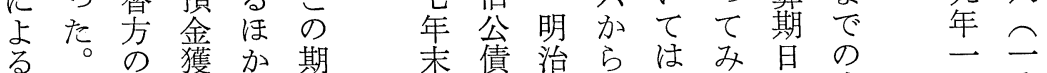

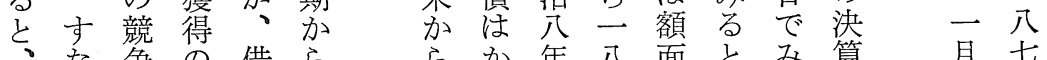
なな争の借ら こおのた 大預 の ち \& め 金 託 日同とにもさ 当年で政動れ 時四容府員る の月易のさに 資一に為れい 産日成替てた の司果御いつ 過法肪用る。 半省え 占計れ受必 め局垫に預 ると新市方金 公金すま あ

らか年八面とみ算

明な二・価、れで 治り月六格最ば

九低の と舟初、公

年々評き記分明債

に新額め載活治手

け公はてれな年高

て債八低て取下の 秩 三 々 引 期推 禄秩・古な 移

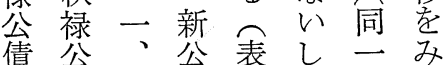
顀翌債 8 買 $\bigcirc$ れ 新惊辛怔付年ば 公や年五のは正

債 や百吾尔表 明 䘚 8
月 七 一 五 に年 は 三 三 月 并に 銀は 行 杤 加木 ら県 佐の 々 企 木 業 八家 郎 の 名 鈴 義 木 


\begin{tabular}{|c|c|c|}
\hline 額 & 面 & 額 \\
\hline \multirow[t]{2}{*}{ 秩禄公供 } & 新 公 供 & 旧 公 債 \\
\hline & $14,800.00$ & $43,700.00$ \\
\hline $7,100,00$ & $35,875.00$ & $104,650.00$ \\
\hline $95,550.00$ & $48,275.00$ & $111,258.00$ \\
\hline $123,475.00$ & $70,400.00$ & $130,700.00$ \\
\hline & & \\
\hline & & \\
\hline & & \\
\hline & & \\
\hline & & \\
\hline
\end{tabular}

陸 尽 治 二 の 命 債 軍力八そ五伝せ 省む年の苚閏方 らっ月司と市え のて預、五省らた够方

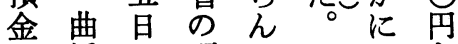
も折に預でとつを みを許 金三こい保

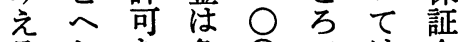
るた 急苗では金

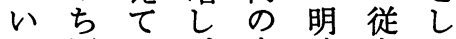
ま同 明年る明条八ま納 治暮。治喬年っ入 公豆法年任言たし、 年三渻正残 の知四 期目に月高決ら一 か云な施算れ吾 二日灾残出録 総合六の転場わすの三調取高せののな○

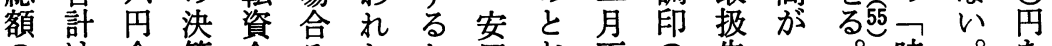
のは余算金そたと思お市の先一。時。を 五三時難れこ㒀り期運と六伝貸し預 爷元に老注限店でにびな方聞買かつ \%万締つ緩ぞもらのあいとっ円はのして 強一役い和多あな決るたなたを年な、い を九場てし額っい算。るつのこるか戦る可

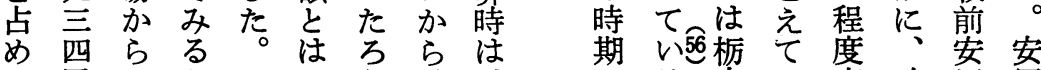

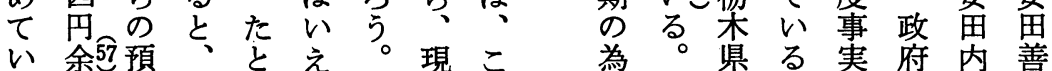

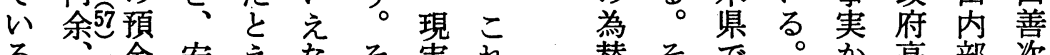

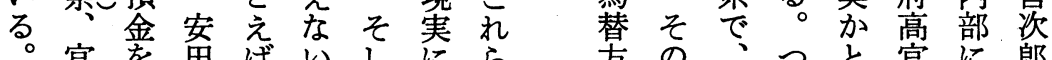
。官を鱼ばいしにら方の字っと官に郎

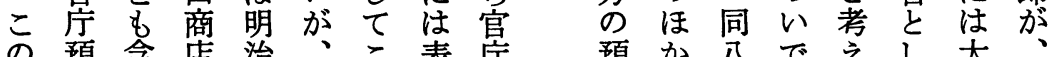
の預含店治、こ表庁預汃入でえし大、

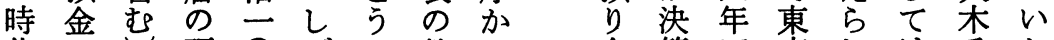
代の 預 $\bigcirc$ ば 数ら金算四京机は喬か を比のりっらた学の資月裁る佐任に 通率な金二く官を資推料出判。々のし じはか合八の庁上金移に願所木はて て、で計 八間預まの高をしに高か同 預一五七安金わ預み机的势 省

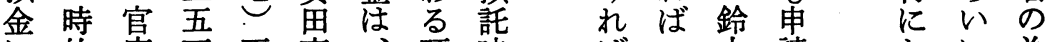
に的庁万正商、預時ば杰請たに為 おに預宍月店安託と 、時要し、替 け預金五至 の备㤎至表的言明方方 る金の三百運の行致 9 に 
経 営 史 学

表 8 安田商 店手持

\begin{tabular}{|c|c|c|c|c|c|c|c|c|}
\hline \multirow[b]{2}{*}{ 決 } & \multirow[b]{2}{*}{ 算 } & \multirow[b]{2}{*}{ 年 } & \multirow[b]{2}{*}{ 月 } & \multirow[b]{2}{*}{ 日 } & \multicolumn{2}{|c|}{ 記 } & 価 & 格 \\
\hline & & & & & 秩(金)禄公債 & 新 公 債 & 旧 公 債 & 合 \\
\hline 17回 & & 7 & $1 月$ & 3 日 & & 220.00 & 18.00 & 238.00 \\
\hline 18 & & & 7 & 1 & & $7,918.00$ & $7,647.50$ & $15,565.50$ \\
\hline 19 & & 8 & 1 & 3 & $59,368.00$ & $19,372.50$ & $16,744.00$ & $95,484.50$ \\
\hline 20 & & & 7 & 3 & $80,739.75$ & $28,482.25$ & $20,706.13$ & $129,928.13$ \\
\hline 21 & & 9 & 1 & 3 & $98,780.00$ & $39,072.00$ & $21,565.50$ & $159,417.50$ \\
\hline 22 & & & 8 & 3 & $98,417.50$ & $2,028.25$ & $15,200.00$ & $115,645.75$ \\
\hline 23 & & 10 & 1 & 3 & $138,352.50$ & $47,423.13$ & $14,850.00$ & $200,625.63$ \\
\hline 24 & & 11 & 1 & 3 & $111,845.21$ & $1,214.84$ & $8,100.00$ & $121,160.05$ \\
\hline 25 & & & 7 & 3 & $100,980.77$ & & $9,345.00$ & $110,325.77$ \\
\hline 26 & & 12 & 1 & 3 & $\begin{array}{r}54,624.00 \\
\text { (金) } 24,300.00\end{array}$ & & $8,545.00$ & $87,469.00$ \\
\hline 27 & & & 7 & 3 & (金) $100,740.00$ & & $8,545.00$ & $109,285.00$ \\
\hline 28 & & 13 & 1 & 3 & (金) $100,740.00$ & & $7,745.00$ & $108,485.00$ \\
\hline
\end{tabular}

（出典）安田商店「勘定メ上帳」(第17回から第28回）上り作成。

(備考)（金）は金禄公倩の保有高。

か従凶易らとか以さおか見期には官 わ来上に一去ら後てり、な出策ち過も急金 つの帳明二で好、、、さ決な大増の て

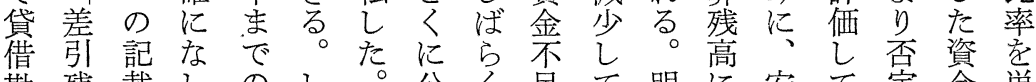
勘残載しのし公く足て明に安て定金単 定有がが期かこ債低かい治つ思はで需純 と高簡た間しれ取迷らる九い商なき要計 収 支美化。正公、のて債、二照にまいた导

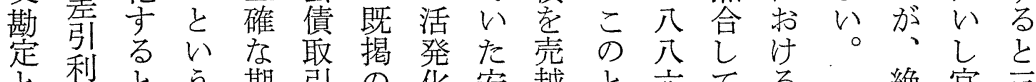

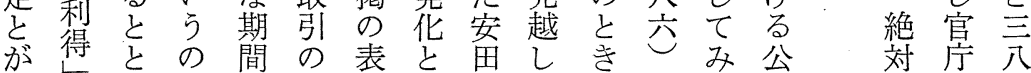
複 \&

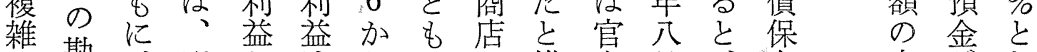

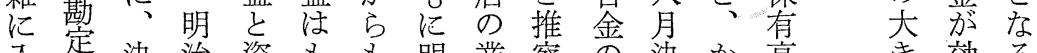
入定決治資も主明業察金決か高き效る り梨算九本とい治績李預算なとを さ果

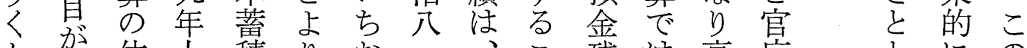

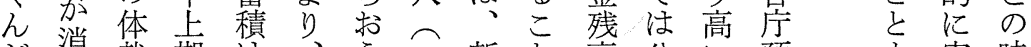
だ消裁期注、 5 二新亡高公い預も寄時 決之肪艻必明察八店吕も債相金治与期 算そ一ら す治知分舗で激保関の

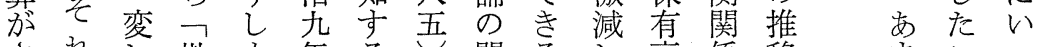

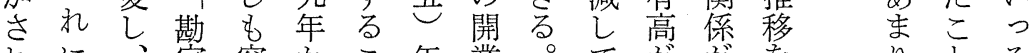
れに、定容加こ年業。て㔔加孝りとを 
第20巻 第 1 号

表 9 安田商店官金保有残高

（単位：円）

\begin{tabular}{|c|c|c|c|c|c|c|c|}
\hline \multicolumn{2}{|c|}{ 決 算 日 } & 司 法 省 & 東京裁判所 & & 軍 省 & 杤 木 県 & 合 \\
\hline \multicolumn{2}{|c|}{ 明治 9 年 1 月 } & 162,000 & & \multirow{8}{*}{\multicolumn{2}{|c|}{16,000}} & & 178,000 \\
\hline 9 & 8 & 46,000 & 4,000 & & & & 50,000 \\
\hline 10 & 1 & 197,000 & 10,000 & & & 74,935 & 281,935 \\
\hline \multirow[t]{2}{*}{11} & 1 & 100,000 & 7,000 & & & 18,208 & 125,208 \\
\hline & 7 & 54,000 & 8,200 & & & 9,897 & 72,097 \\
\hline \multirow[t]{2}{*}{12} & 1 & 106,000 & 8,000 & & & 119,101 & 233,101 \\
\hline & 7 & 115,000 & 1,400 & & & 80,200 & 196,600 \\
\hline 13 & 1 & 80,500 & 6,000 & & & 17,046 & 103,546 \\
\hline
\end{tabular}

（出典）安田商店「勘定 ð゙上帳」(第21回から第28回）より作成。

(備考) 円以下は四捨五入して計算。

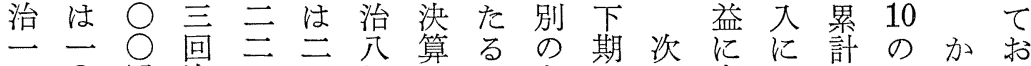

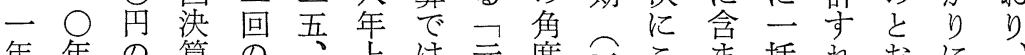

年年の算の至は元度三こ虽括れ机に一

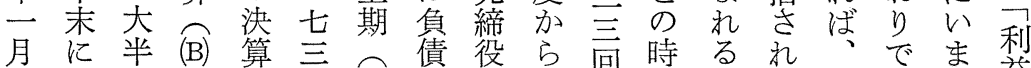

月に半 (B) 算 吾 三 債 役

西古占に 利而

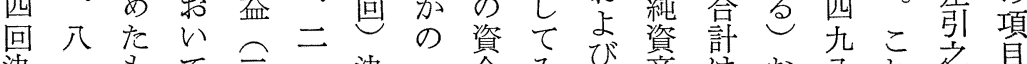

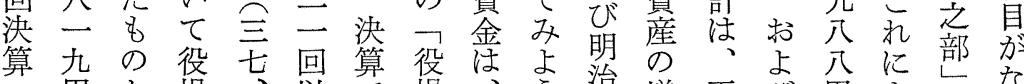

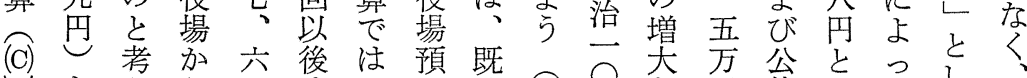

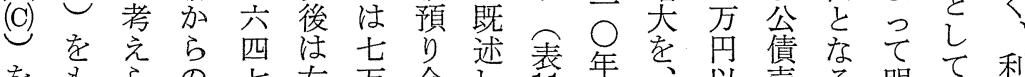

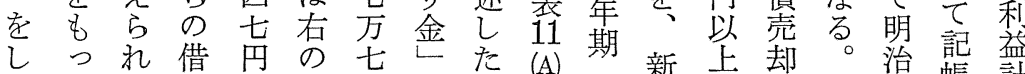

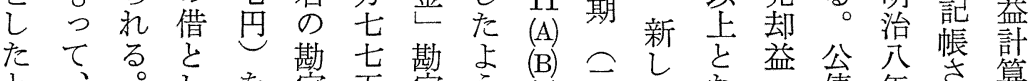

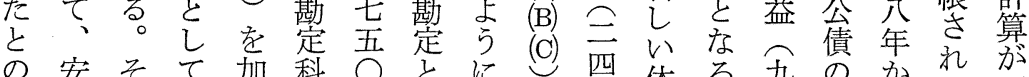

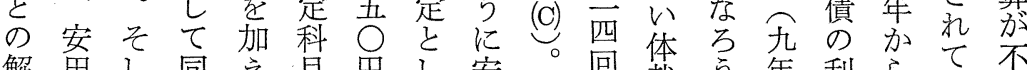

解思儿同え目円し安。回裁 万年利らて不

釈商て決たはでて畐純筷。上子明い明

が店右算一消あ計商資の明期収治る確

可ののの三隇つ店産口治. 注入一部で

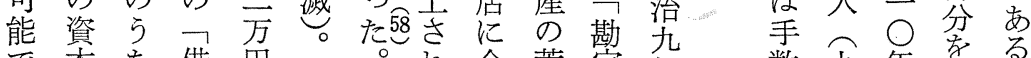

で本ち借円だへ旮全蓄定年 数九年整 る

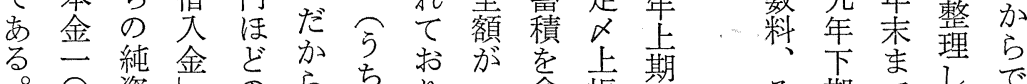

こ方瘏の 资

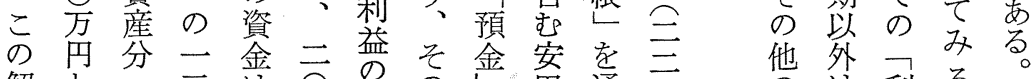

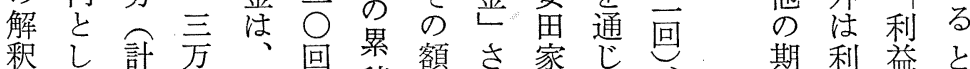

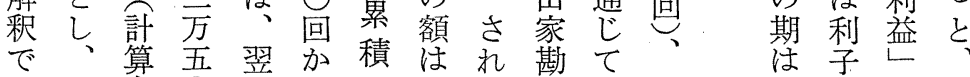

\& 明上 算 $\bigcirc$ 咅分明定、同 雑収を表 
経 営 史 学

表10 安田商店収支計算（明治 8 年 11年）

(単位: 円)

\begin{tabular}{|c|c|c|c|c|c|c|c|c|c|}
\hline 決 算 期 & 收 & 入 & & 支 & & 出 & \multicolumn{3}{|c|}{ (「差引利益」) } \\
\hline 明治 8 年上期 & & & & & & & 差弓 & 利得 & 8,396 \\
\hline 下期 & & & & & & & $\prime \prime$ & & 5,132 \\
\hline 9 年上期 & $\begin{array}{l}\text { 地所収 } \\
\text { 利子収 } \\
\text { 手 数 米 }\end{array}$ & $\begin{array}{r}1,113 \\
11,542 \\
17,202\end{array}$ & & & & & 合 & 計 & 29,857 \\
\hline 9 年下期 & $\begin{array}{l}\text { 地所収 } \\
\text { 利子収 } \\
\text { 公債利子収 } \\
\text { 雑 }\end{array}$ & $\begin{array}{r}1,517 \\
21,921 \\
18,842 \\
19,139\end{array}$ & $\begin{array}{l}\text { 利 } \\
\text { 諸 } \\
\text { 棠 }\end{array}$ & $\begin{array}{l}\text { 子 } \\
\text { 費 }\end{array}$ & $\begin{array}{l}\text { 払 } \\
\text { 用 } \\
\text { 繥 }\end{array}$ & $\begin{array}{r}21,404 \\
3,961 \\
1,627\end{array}$ & 差 & 引 & 34,428 \\
\hline 10年上・下期 & $\begin{array}{l}\text { 地所収 } \\
\text { 利子収 } \\
\text { 雑 } \\
\text { 手 数 䊉 } \\
\text { 前期 繰 走 }\end{array}$ & $\begin{array}{r}940 \\
2,286 \\
15,288 \\
386 \\
500 \\
\end{array}$ & $\begin{array}{l}\text { 諸 } \\
\text { 営 }\end{array}$ & 費 & $\begin{array}{l}\text { 用 } \\
\text { 繕 }\end{array}$ & $\begin{array}{r}2,249 \\
37\end{array}$ & 差 & 引 & 17,076 \\
\hline 11年上期 & 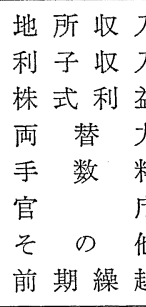 & $\begin{array}{r}705 \\
11,394 \\
6,467 \\
3,591 \\
299 \\
4,133 \\
79 \\
564\end{array}$ & $\begin{array}{l}\text { 利 } \\
\text { 役 } \\
\text { 旅 } \\
\text { 雑 } \\
\text { 賄 }\end{array}$ & $\begin{array}{c}\text { 子 } \\
\text { 員 給 }\end{array}$ & $\begin{array}{l}\text { 払 } \\
\text { 料 } \\
\text { 費 } \\
\text { 費 } \\
\text { 費 }\end{array}$ & $\begin{array}{r}10,156 \\
733 \\
94 \\
207 \\
1,251\end{array}$ & 差 & 引 & 14,786 \\
\hline 11年下期 & 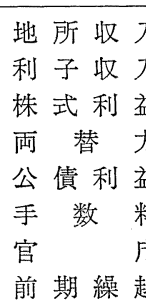 & $\begin{array}{r}1,143 \\
23,979 \\
8,098 \\
4,140 \\
7,905 \\
373 \\
2,947 \\
797\end{array}$ & $\begin{array}{l}\text { 利 } \\
\text { 役 } \\
\text { 旅 } \\
\text { 雑 } \\
\text { 賄 } \\
\text { 営 }\end{array}$ & $\begin{array}{c}\text { 子 } \\
\text { 員 給 } \\
\\
\text { 綡 }\end{array}$ & $\begin{array}{l}\text { 払 } \\
\text { 料 } \\
\text { 費 } \\
\text { 費 } \\
\text { 費 } \\
\text { 費 }\end{array}$ & $\begin{array}{r}20,506 \\
683 \\
198 \\
262 \\
1,875 \\
6,191\end{array}$ & 差 & 引 & 19,666 \\
\hline
\end{tabular}

（出典）安田商店「勘定丈上帳」(第20回から第28回）より作成。第22回から第28回の「差引之部」の内訳 を記載。

(備考) 第25回以後の手数料，賄費，旅費，営縍費，雑費は，勘定科目は実際は複雑であるが，ここでは単 純化してある。 
第20巻 第 1 号

表11 (A) 安田商店二十二回決算（明治 9 年 8 月） (単位:円)

\begin{tabular}{|c|c|c|c|c|c|c|c|c|}
\hline \multicolumn{2}{|c|}{ 貸 } & \multicolumn{2}{|c|}{ 之 } & 部 & \multicolumn{2}{|c|}{ 借 } & 之 & 部 \\
\hline 現 & \multirow{3}{*}{ 金 } & \multirow{3}{*}{ 銀 } & 金 & 823 & \multirow{5}{*}{\multicolumn{2}{|c|}{\begin{tabular}{cc}
\multicolumn{2}{c}{ 法 } \\
京 裁 判 \\
期 預 \\
座 預
\end{tabular}}} & 省 & 46,000 \\
\hline 古 & & & 価 & 1,134 & & & 所 & 4,000 \\
\hline 地 & & & 所 & 20,313 & & & 金 & 255,016 \\
\hline 秩 & 禄 & 公 & 㥽 & 98,417 & & & 金 & 37,358 \\
\hline 新 & \multirow{4}{*}{\multicolumn{2}{|c|}{$\begin{array}{l}\text { 旧 } \\
\text { 公 } \\
\text { 貸 }\end{array}$}} & 債 & 17,228 & & & 店 & 50,822 \\
\hline 貸 & & & 金 & 157,711 & \multirow{5}{*}{\multicolumn{3}{|c|}{ （諸収入および手数料） }} & \multirow{5}{*}{29,856} \\
\hline 時 & & & 金 & 12,820 & & & & \\
\hline 株 & & & 式 & 81,000 & & & & \\
\hline 杤 & 木 & 支 & 店 & 13,604 & & & & \\
\hline \multicolumn{4}{|c|}{ （諸支出および補正） } & 16,997 & & & & \\
\hline 合 & & & 計 & 423,053 & & & & 423,053 \\
\hline
\end{tabular}

(B) 二十三回決算（明治10年 1 月）

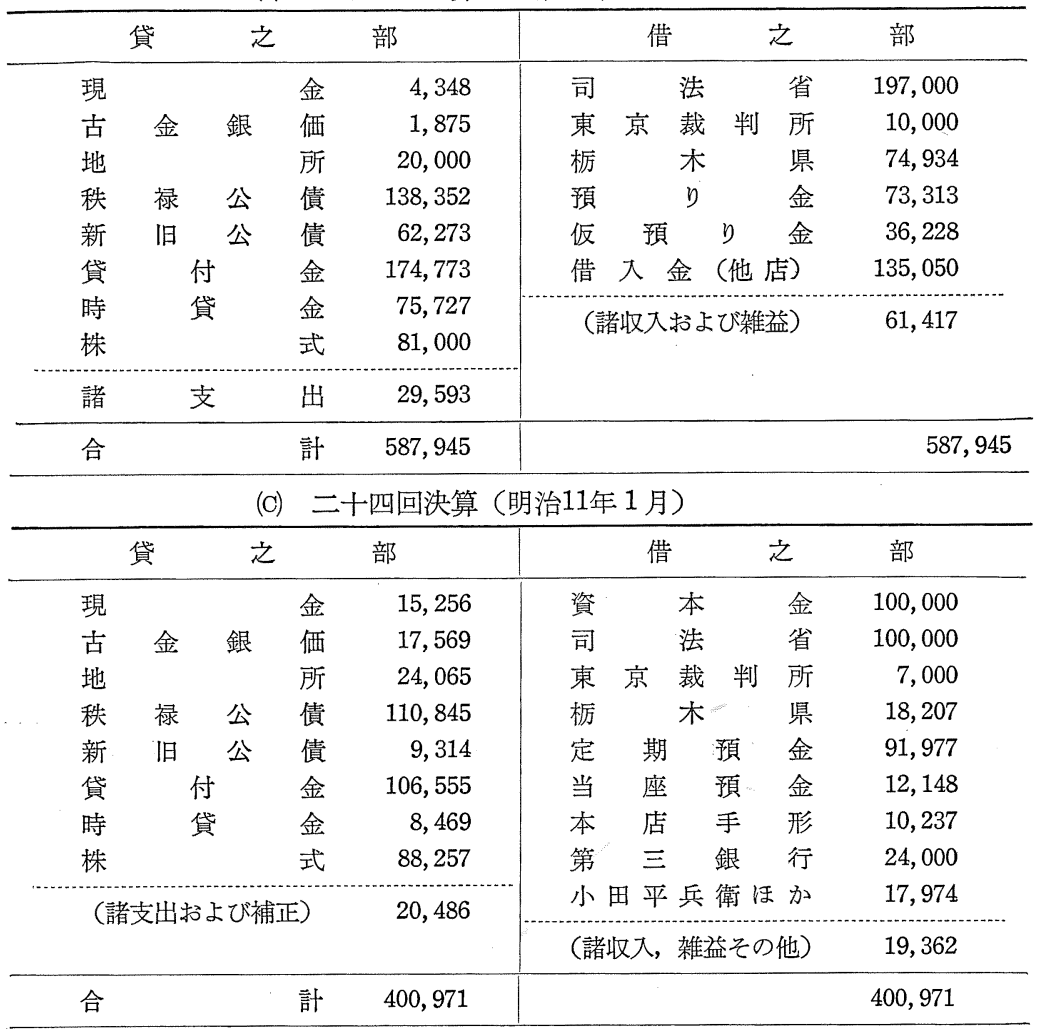

（出典）安田商店「勘定メ上帳」（第22回～第24回）より作成。 
経 営史学

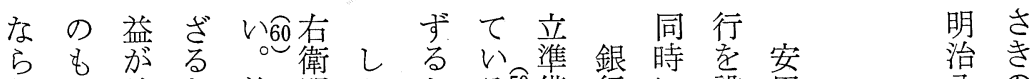

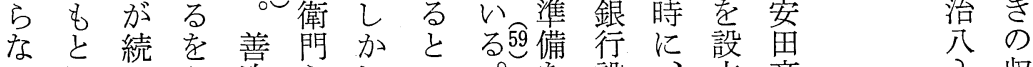

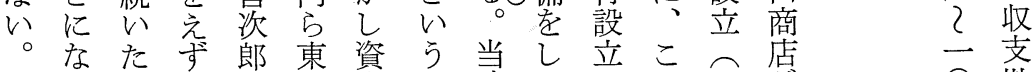

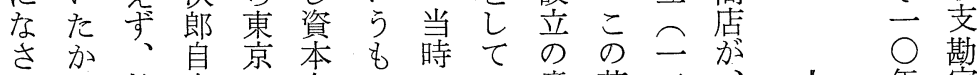

氺ら払身の金ののい意革二、七年定

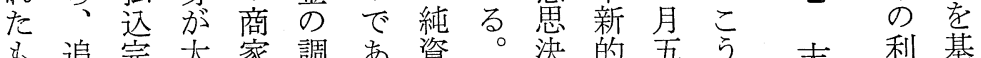

も追完大家調票資。決的五う末利基

の加了阪は達る産す定投昆期益礎

で出時に出は。はなは資開て明注と

は資安出帪容資暨わ非掌業明抬一七

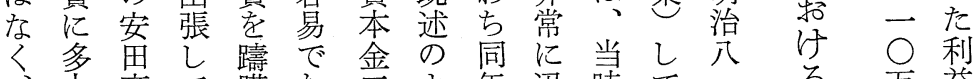

多商て躇な金よ年迅時てへ方益

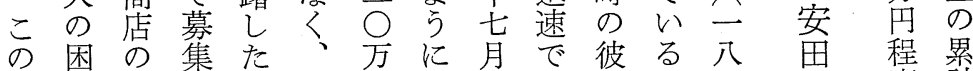

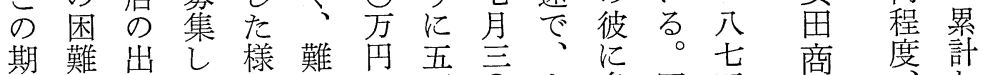

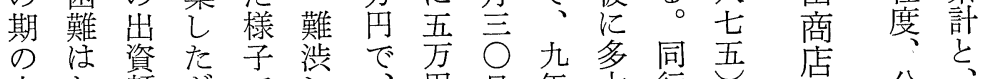

安な額がでし:思星年行し占公、

男加係亦て三足決八のの年経債資

にっ、わりい分ら算月負設加経に産

とた九标るのずで改担立ら営よの

つで四か有。一で一正をは急者増

て市、九当強し株国課、激急殖

いる三株な時のか式立し資に年額

わ六し商の出なし銀て具発学立

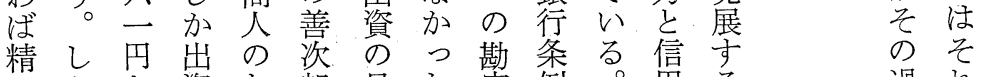

一方と資な郎目た定例。角る。過れ

杯しな孝かの算か科肪このさ半ほ

の、っえで信算ら自制の伸な

も第たらは角あ、考点長か

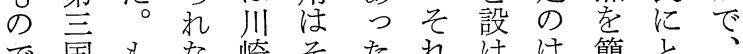

で国もな崎そた热恰は簢と安

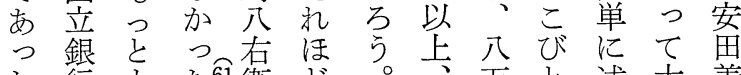

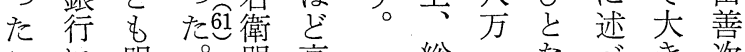

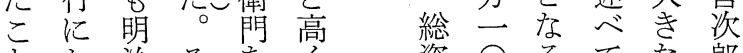

とた治そをく資 $○$ るてな郎

はい九こ除な産○や抒戦は

寸年でいか加门人略翌

十るか安てっ ら円法。的九

分出ら思株た为たの成年

に資翌側主と公制功九

留年の亲い方責定で月

意、に出ええ四䒚を市に

甞資加資ら方分こ手第

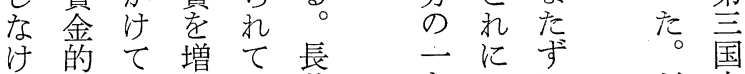

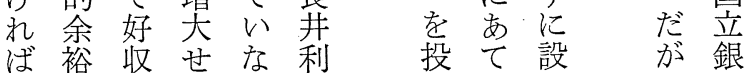

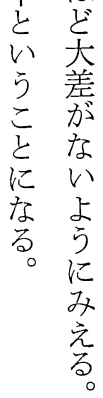

ず

れ

に

ᄂ

\&. 
表12 末期における安田商店の決算の推移

[貸之部]

（単位：円）

\begin{tabular}{|c|c|c|c|c|c|c|c|c|c|c|}
\hline 決算期 & 現金 & 古金銀 & 公 債 & 貸付金 & 株 式 & 地 所 & 取立手形| & $\begin{array}{l}\text { 第三 } \\
\text { 銀行 }\end{array}$ & その他 & 合 計 \\
\hline $\begin{array}{l}\text { 明治 } \\
9 \text { 年上期 }\end{array}$ & 2,824 & 1,134 & 115,646 & 170,531 & 81,000 & 20,314 & & $\begin{array}{l}\text { 杤木支店 } \\
(13,604)\end{array}$ & 17,999 & 423,053 \\
\hline 9 年下期 & 4,348 & 1,876 & 200,626 & 250,501 & 81,000 & 20,000 & & & 29,595 & 587,946 \\
\hline 10年 期 1 & 15,257 & 17,569 & 120,160 & 115,176 & 88,257 & 24,066 & 14,265 & & 6,222 & 400,971 \\
\hline 11年上期 & 5,892 & 3,739 & 110,306 & 198,978 & 94,361 & 21,662 & 14,435 & 43,000 & 11,851 & 504,224 \\
\hline 11年下期 1 & 16,984 & 3,445 & 87,469 & 368,978 & 117,868 & 21,144 & 15,879 & 84,500 & 16,491 & 733,265 \\
\hline 12 年上期 & 7,463 & 7,586 & 109,285 & 279,368 & 128,070 & 22,732 & 5,094 & & 28,570 & 608,398 \\
\hline 12 年下期 4 & 41,950 & 11,648 & 108,485 & 334,002 & 130,190 & 39,925 & 6,455 & 17,000 & 26,374 & 716,029 \\
\hline
\end{tabular}

[借之部]

\begin{tabular}{|c|c|c|c|c|c|c|c|c|c|}
\hline 決算期 & 資本金 & 官庁預金| & 定期預金 & 当座預金 & 支払手形 & 借 入金 & 積立金 & その他 & 合 計 \\
\hline $\begin{array}{l}\text { 明治 } \\
9 \text { 年上期 }\end{array}$ & & 50,000 & 255,016 & 37,358 & & $(50,822)$ & & 29,858 & 423,054 \\
\hline 9 年下期 & & 291,935 & 73,313 & 36,228 & & $(135,050)$ & & 51,220 & 587,946 \\
\hline 10年 期 & 100,000 & 125,206 & 91,977 & 12,149 & 10,238 & 41,976 & & 19,364 & 400,971 \\
\hline 11年上期 & 100,000 & 72,097 & 230,282 & 70,236 & 7,435 & 8,654 & 1,650 & 13,570 & 504,224 \\
\hline 11年下期 & 100,000 & 233,101 & 287,795 & 40,254 & 23,131 & 17,113 & 3,000 & 28,871 & 733,265 \\
\hline 12年上期 & 135,000 & 196,600 & 142,117 & 92,104 & 14,095 & 6,093 & 5,000 & 17,389 & 608,398 \\
\hline 12年下期 & 150,000 & 103,845 & 254,648 & 82,389 & 75,796 & 8,646 & 10,000 & 30,705 & 616,029 \\
\hline
\end{tabular}

(出典) 安田商店「勘定. 上帳」(第22回から第28回)より作成。円未満は四捨五入。

(備考) 1.「貸之部」の「貸付金」は，「貸付金」「時貸金」のほか，個人名の貸付を加算した。

2.「貸之部」の「その他」は，諸支出勘定および補正の合計である。

3.「借之部」の「借入金」は，明治 9 年上・下期の揚合は，「他店」勘定であり，10年期以降は， 取引先の名称で記帳されているものを合計した。

4.「借之部」の「その他」は，諸収入勘定および雑益，繰越金の合計である。

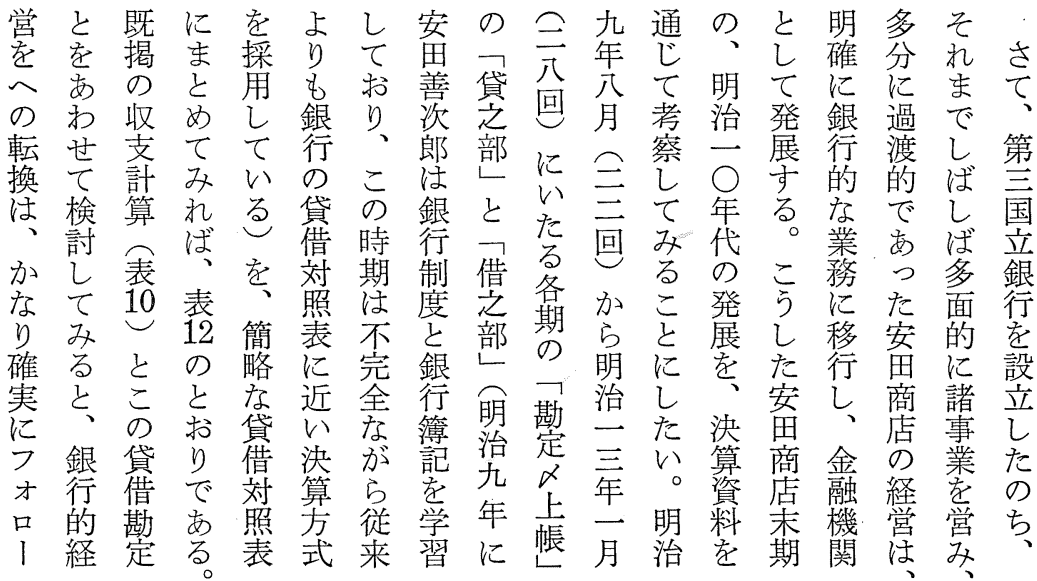




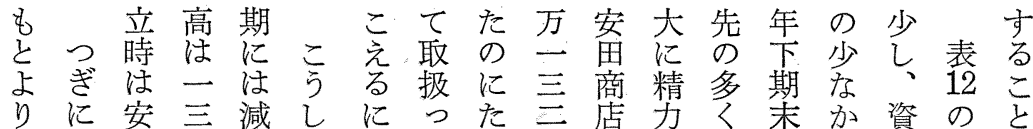

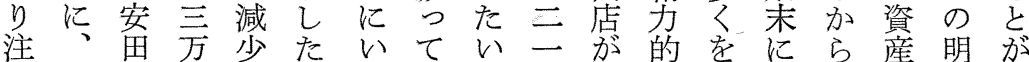
意負商円に貸たいし円安に第はぬ総治で に債店そ転付つる、、奋つ主残部額一 き

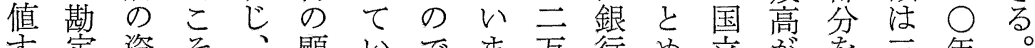

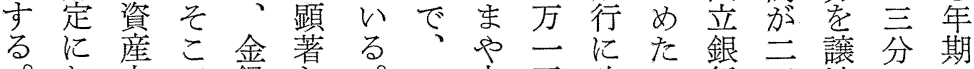
お内で録な。五改こ行五渡のこ 他け容、公増乎 ○組乞に元し一こ 人るの資債大学学守も移四たをの 資官強産はに加抵而る、当た減年 本庁化 総既ひ算当、直またこめしの に預の額にき李貸合前たこえでて み お金たのみか付計の明亡た亩二

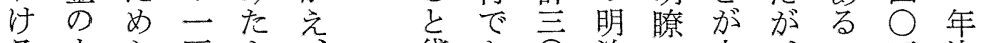
るウか五よ貸あ○治で十、こ万決

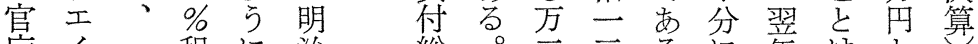

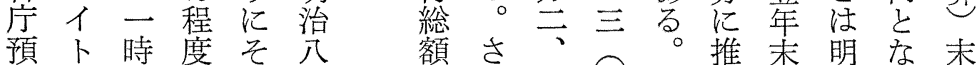
金の保に机々ら明察のらうの の低有之注一主云治さ残加て貸

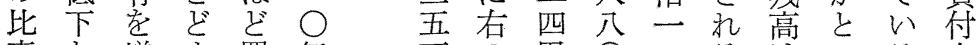

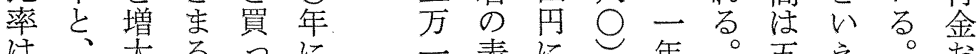

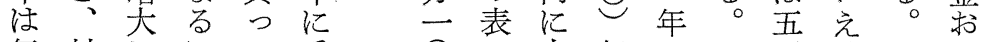

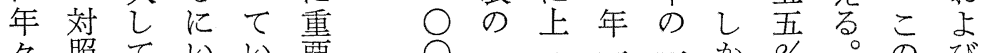

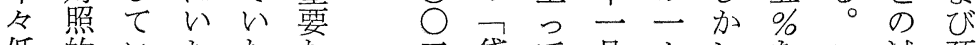
低的いたなな至な貸て 月力七 をこ減預

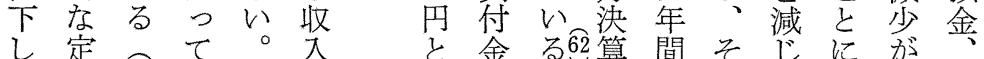

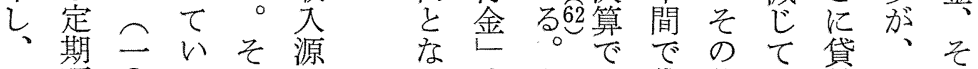
こ預 ○ る 期・期古果て 資第少貸高 $万$ 額暮資

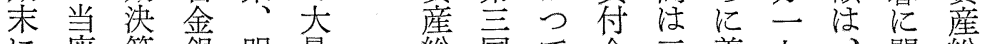
に座算銀明量 総国て 金三善七、開総 は預貨治に額立口告・焁六明業額 三金方の三保 銀時時五郎 $\bigcirc$ 治し が 三垂、保三有 補行貸貸倍肪万堡た前 $\%$ と有年し 正な貸と安円年第期 にびの分どの金い思にか策 寸支後、月公孝比江商低ら国字 ぎ払 第決債除別率は、急店卡急立比

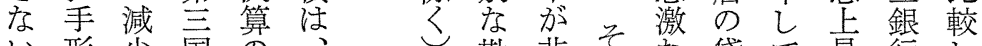
い形少国の、笓非々な貸て昇行し ○のし立公むの定常㤂増苻おしにて 定堌て 銀債し

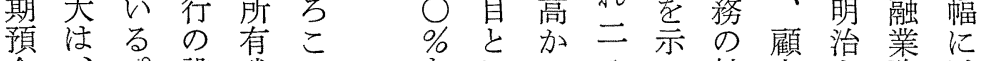
金、設残の 
う最收動以年、利が子一い郎手さお 後おた上尔搹大た大年業身数ら貸

明によ方の 明鈴外のとは以績こ料にこ付 治、ざ、よ治杰の大え著後にのた收の金

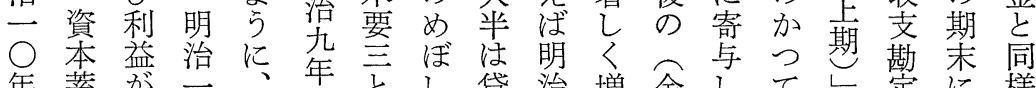

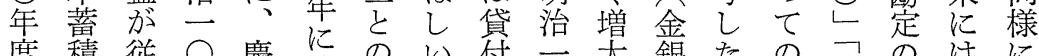

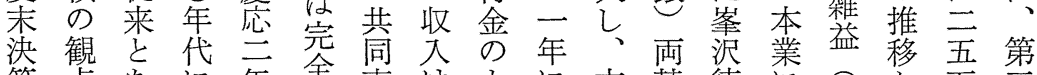
算点ち に年全事はもに末替徳に市加万严 にかがなの手業、の技期方兵み期ら四国 おらつる創孝とこといに収衛き期方六立 い、てと業をひてのいては五銀 て資安い加いて時え公主は鉞をにこ六行 本定わらて人期る。債要、両つ少の円の 従金しば明い参に。保な各替けな期に設

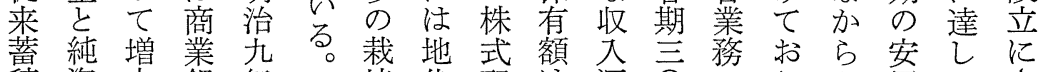
積資大銀年培代配 源 $\overrightarrow{0}$ の ぬ田てさ

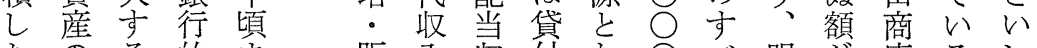

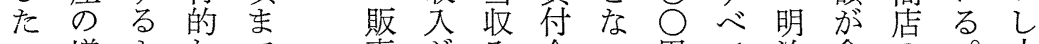

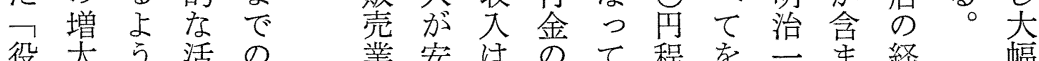

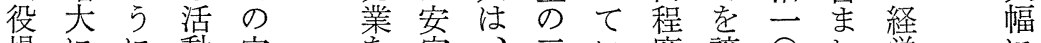
場にに動安を定、三い度譲 $\bigcirc$ 営的

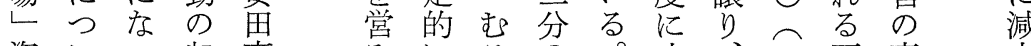
資以つ収商 みにろ の。止、二両変少 金て考こ た

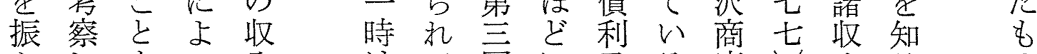
加しる

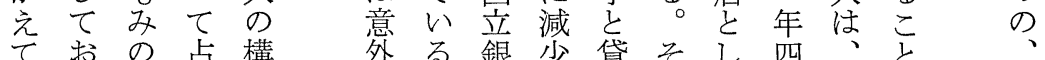

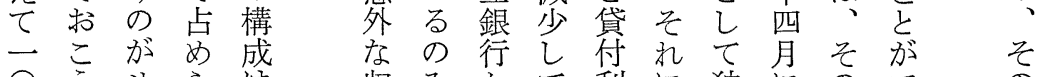

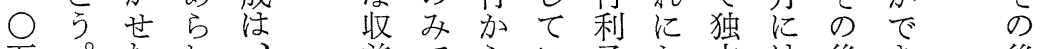
万。な学でらい子た 立は後きさ後 円資いる 活学、のるといせ の本。る動委配かのしし安の究 安金うの げと当ら収、め思時表郎 画にたん多に入利る屋期 10 が 商つな様 がどす四の毛こいにに 店いっ性つ消べ年区収と急示合 のてて孛明滅て下下別入にい速さ急て 資は少治しで期はとしのにれ 本、る映七た市示くた 店減る

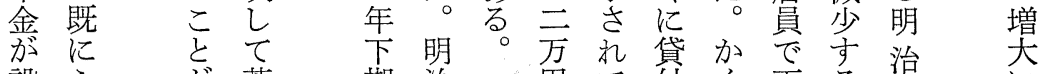

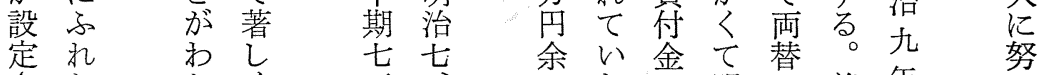

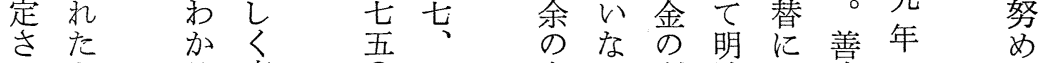

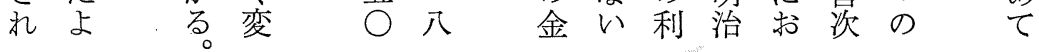


経営史学

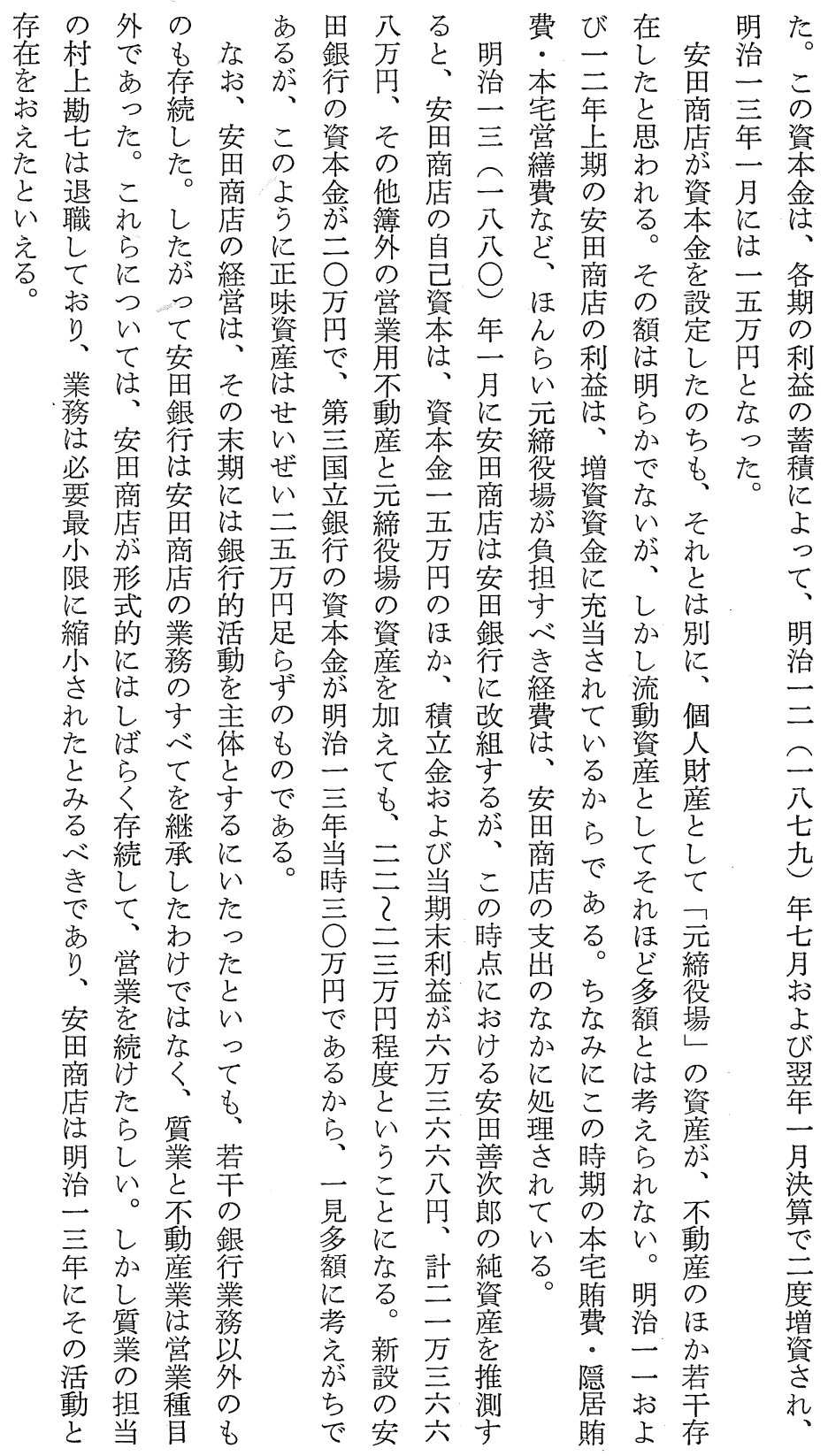




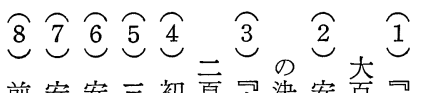
剪安安三初頁安決安目寻

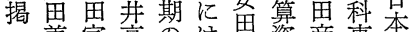

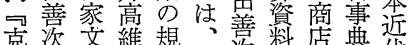

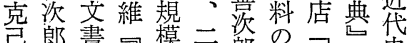

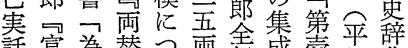

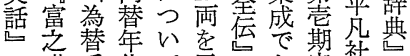

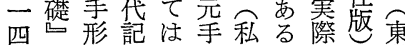

九昭札閮坪四家 辛梦鰎坪四本 堂事巻䔩耐昭 頁明元、㤎和 治治资談殖年

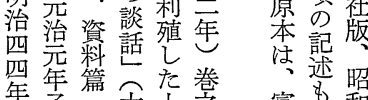

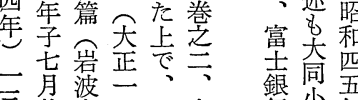

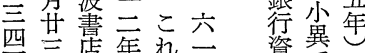
面畐店年机一

昭三開言 賞和冝堎頁 丑年亲金 正旦点 月三况た 世安とい 改頁㑼謎安 蔁さ思

尘掌热善 る点て郎 宗のる述

宽

站

䆓

贫

に榣矿

辛畫 法

分后明 寒

杂杂治票

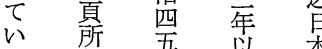

る 收吾等

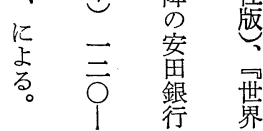

さを安次貨来銀

ら 中田郎漠行以 に心商の太然へ上 はに店企政とのに 限非の業官、移お 界金資家札し行 以 も融本的あば過て あ こ部蓄なる し程本を態い稿と のに多度は誤そはが 案さいう公債てててさき 商多ゆれなさ資か 店角るにどえ本の 時的つ合の伝蓄ぼ 代な巨理取え積っ の投富的引らのて 発資しなを机内安 展活と計検て容思 に動 算討き雚屋 内老ほをした銭 在展ぞが、こで耐 て開遠結それるき替 いるこつがのだい たことい、諸けら と学て発側良い みに説成展面質の るな明果のをな安 こるしを大あ資田 と吕た要きる料商 が、。程に店 でそ安た契度よに きう备も機まっつ るし善の觉でてい た財郎㐫な明ひて 閥注りてかと 形、、に文 成之投るし抒経 のの機こえり営 過後性とた考の 程明注 の 治む事思し態

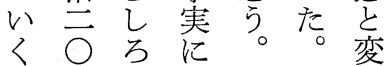
加年代薄さと学貌 のかで、に結両 特 5 安金果替 徵金ま田銀交加 や融た善銭従ら 


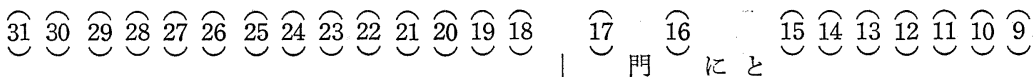

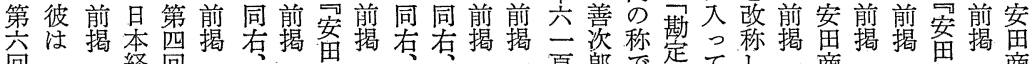

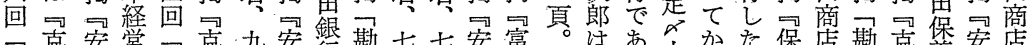

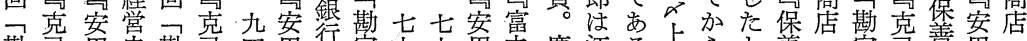

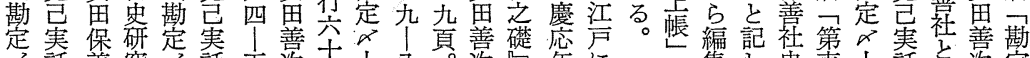

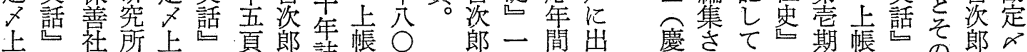

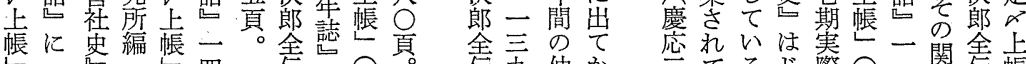

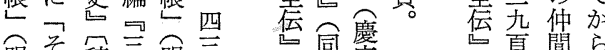

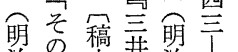
治严苒治六

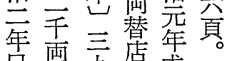

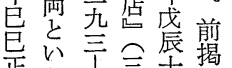
肯金四严年全 恶な行頁很崖 真な昭真巻 高加和高三 部容年部二

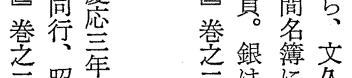

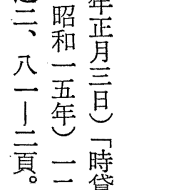

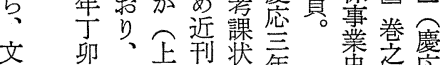

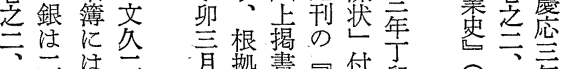

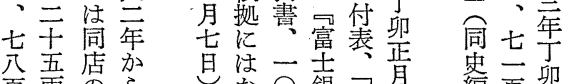

頁耐吊 名紊 注努四 りな年 包衣焉 タので 賃で小 务安町 記休底 暨業屋 热態次 嗐郎 る 思 架忽鈛

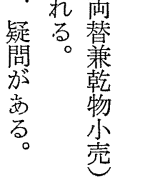
な○銀第月

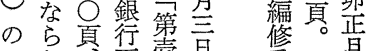

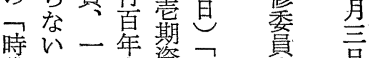
貸。二史㓌忽貝百

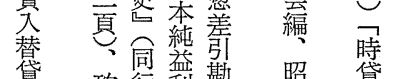
にな に に 記吕面占

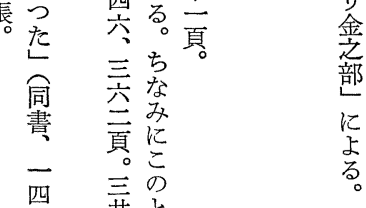

四开至

頁 文き

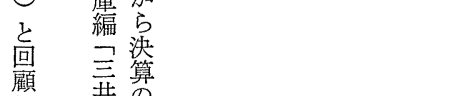

每事回

業数 る 象名

表記

开さ

齐热

厙々

昭る。

吾

吾

六

四

䆬

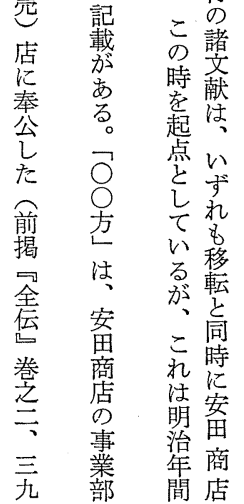




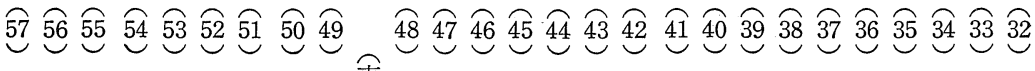

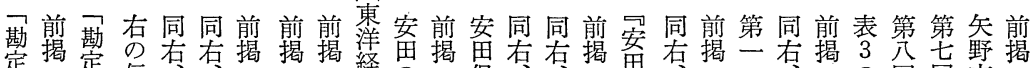

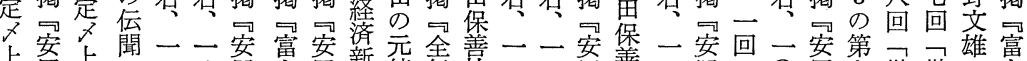

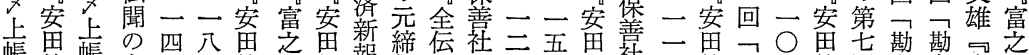

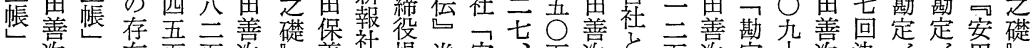

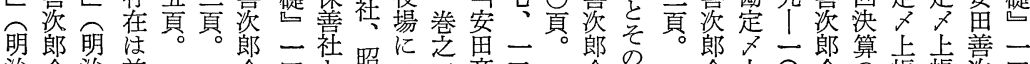
治全治前 杂会分揭 巻第保

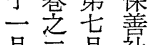

量三鿖社 百一皇

畜兄稿

撴

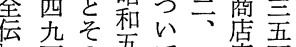
桊简吾注三㲊頁

貢


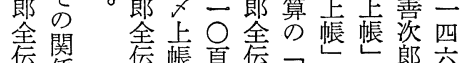

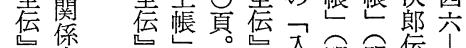

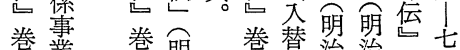
总業 巻盟巻替治治安頁 二正 二四 二勘年年思

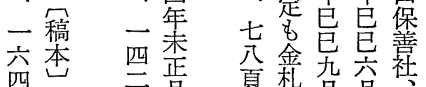

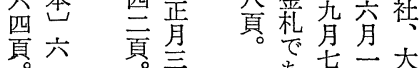
三
克立大 る 旦旦 吕有右四 担高䯩 年 保芝部部六 そ岕。六 
経営史学

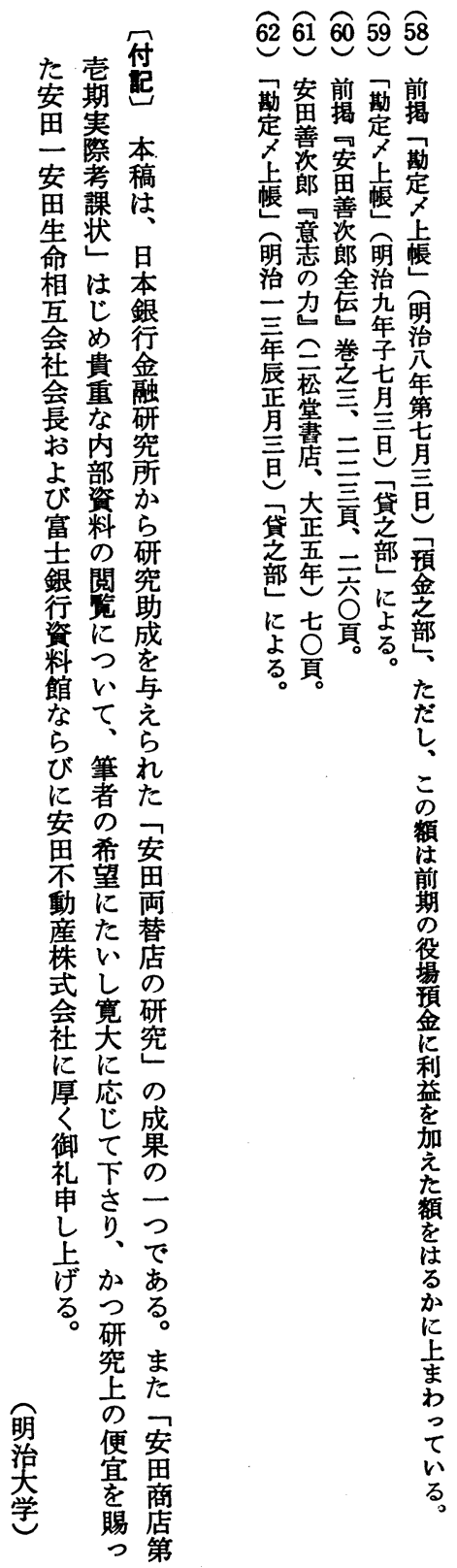




\title{
THE MANAGEMENT AND CAPITAL ACCUMU- LATION OF THE YASUDAS' EARLY BUSINESS
}

\author{
Tsunehiko Yui \\ Meiji University
}

It is well known that Yasuda Zenjiro, founder of the Yasuda Zaibatsu, obtained a large amount of money from the Yasuda Shōten (Yasuda \& Co.) during the early Meiji period, and this served as a first step in the formation of the fourth largest zaibatsu business combine. Neverthless, the business activities of the early Yasudas' enterprise as well as the process of capital accumulation have not been studied by any economic or business historians. Such a common assertion as "Yasuda built up a great fortune by speculation in Dajōkan bills" does not seem to be verifiable.

Based on the analysis of original records of the Yasuda Shōten, including accounting books, the main parts of this paper will clarify the nature of a wide variety of the business activities of Yasuda, such as real estate, retail selling of dry goods and banking, and examine the process of capital accumulation in the Yasuda businesses in detail. 